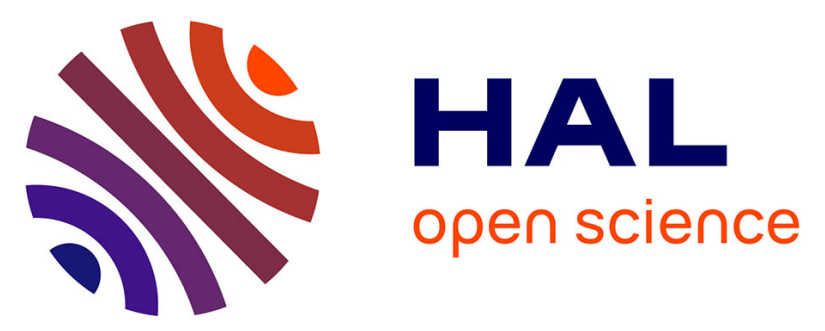

\title{
High gellan gum concentration and secondary somatic embryogenesis: two key factors to improve somatic embryo development in Pseudotsuga menziesii [Mirb.]
}

Marie-Anne Lelu-Walter, Florian Gautier, Kateřina Eliášová, Leopoldo Sanchez, Caroline Teyssier, Anne-Marie Lomenech, Claire Le Mette, Cathy Hargreaves, Jean-François Trontin, Cathie Reeves

\section{To cite this version:}

Marie-Anne Lelu-Walter, Florian Gautier, Kateřina Eliášová, Leopoldo Sanchez, Caroline Teyssier, et al.. High gellan gum concentration and secondary somatic embryogenesis: two key factors to improve somatic embryo development in Pseudotsuga menziesii [Mirb.]. Plant Cell, Tissue and Organ Culture, 2018, 132 (1), pp.137-155. 10.1007/s11240-017-1318-0 . hal-02621942

\section{HAL Id: hal-02621942 \\ https://hal.inrae.fr/hal-02621942}

Submitted on 26 May 2020

HAL is a multi-disciplinary open access archive for the deposit and dissemination of scientific research documents, whether they are published or not. The documents may come from teaching and research institutions in France or abroad, or from public or private research centers.
L'archive ouverte pluridisciplinaire HAL, est destinée au dépôt et à la diffusion de documents scientifiques de niveau recherche, publiés ou non, émanant des établissements d'enseignement et de recherche français ou étrangers, des laboratoires publics ou privés. 
Version définitive du manuscrit publié dans / Final version of the manuscript published in :

"High gellan gum concentration and secondary somatic embryogenesis: two key factors to improve somatic embryo development in Pseudotsuga menziesii [Mirb.]"

Marie-Anne Lelu-Walter ${ }^{1 *}$, Florian Gautier ${ }^{1,2}$, Kateřina Eliášová ${ }^{3}$, Leopoldo Sanchez ${ }^{1}$, Caroline Teyssier ${ }^{1}$, Anne-Marie Lomenech ${ }^{4}$, Claire Le Metté ${ }^{1}$, Cathy Hargreaves ${ }^{5}$, JeanFrançois Trontin ${ }^{6}$, Cathie Reeves ${ }^{5}$

1 INRA, UR 0588, Amélioration, Génétique et Physiologie Forestière, 2163 Avenue de la Pomme de pin, CS 40001 Ardon, F-45075 Cedex 2, France

2 Université de Limoges, Laboratoire de Chimie des Substances Naturelles, 123 avenue Albert Thomas, 87000 Limoges, France

3 Institute of Experimental Botany CAS, Rozvojová 263, Praha 6-Lysolaje, 165 02, Czech Republic

4 Plateforme Protéome, Centre de Génomique Fonctionnelle, F-33000 Bordeaux, France

5 Scion, Private Bag 3020, Rotorua 3046, New Zealand

6 FCBA, Pôle Biotechnologie et Sylviculture Avancée, Campus Forêt-Bois de Pierroton, 71 route d'Arcachon, 33610 Cestas, France

*Corresponding author: marie-anne.lelu-walter@inra.fr

\title{
Key message
}

Vegetative propagation of Douglas-fir through somatic embryogenesis was improved at the maturation step (multi-scale analysis: biology, cytology, protein pattern) offering routine production of high-quality somatic seedlings from selected genotypes.

\begin{abstract}
Douglas-fir is a conifer species of major economic importance worldwide, including Western Europe and New Zealand. Herein we describe some characterization and significant refinement of somatic embryogenesis in Douglas-fir, with focus on maturation. The most typical structures observed in the embryonal masses were large polyembryogenic centres (up to 800-1500 $\mu \mathrm{m}$ ) with a broad meristem, creating a compact cell "package" with suspensor cells. Singulated somatic embryos composed of both a embryonal head (300-400 $\mu \mathrm{m})$ and long, tightly arranged suspensor were also frequent. Embryo development was enhanced following embryonal mass dispersion on filter paper discs at low density (50-100 mg fresh mass). Moreover, increasing gellan gum concentration in maturation medium (up to $10 \mathrm{~g} \mathrm{~L}^{-1}$ ) improved both the quantity and quality of cotyledonary somatic embryos (SEs), which were subsequently able to germinate and develop into plantlets at high frequency. Embryogenic yield was highly variable among the seven embryogenic lines tested (27-1544 SE g ${ }^{-1}$ fresh mass). Interestingly secondary somatic embryogenesis could be induced from cotyledonary SEs of both low- and highly-productive lines with some useful practical outcomes: secondary lines from low-performance lines (30$478 \mathrm{SE} \mathrm{g}^{-1}$ fresh mass) displayed significantly higher embryogenic yield (148-1343 SE g ${ }^{-1}$ fresh mass). In our best conditions, the total protein content in cotyledonary SEs increased significantly with maturation duration (up to $150 \mu \mathrm{g} \mathrm{mg}^{-1}$ fresh mass after 7 weeks) but remained below that of mature zygotic embryos $\left(300 \mu \mathrm{g} \mathrm{mg}^{-1}\right)$. The protein pattern was similar in both somatic and zygotic embryos, with major storage proteins identified as 7S-vicilin- and legumin-like proteins.
\end{abstract}

Keywords. Cell density; Cleavage polyembryony; Douglas-fir; Embryogenic potential; Protein pattern; Vegetative propagation 
Version définitive du manuscrit publié dans / Final version of the manuscript published in : Plant Cell, Tissue and Organ Culture, 2018, 132(1) 137-155

\section{Introduction}

There is a growing demand for wood products both in Europe (UN Food and Agriculture Organization -FAO 2010, IUFRO 2015) and worldwide, mostly driven by demographic pressures, continued economic growth and new "green" energy policies. By 2030, FAO predicts a $60 \%$ rise in global demand compared to present levels. These projections pose a threat to existing natural forest, including some of the most valuable ecosystems, which are already under deforestation pressure. One of the most efficient ways to meet such demand without affecting natural forest is a rational development of planted forest, with the use of reproductive species that are improved through breeding, backed-up by a sound seed production system.

Conifers are the most important component of planted forest worldwide, generally due to their superior productivity, and Douglas-fir (Pseudotsuga menziesii [Mirb.] Franco) is one of the conifers of choice. It is grown as a key plantation species in several countries in Europe, North and South America, Canada, New Zealand, and Australia, making it one of the premier timber trees in the world (Hermann and Lavender 1999; Dean et al. 2009; Dungey et al. 2012). In France, it is the second most popular species for afforestation (10.8 million planted in 2016) after maritime pine, and this demand has grown steadily in the last decade $(+26 \%$ between 2009-2012 and 2013-2016, Ministère de l'Agriculture, de l'Agroalimentaire et de la Forêt, DGPE/SDFCB/2017-229). In New Zealand, Douglas-fir is planted on approximately 110 thousand ha and is the second most important exotic softwood after Pinus radiata D. Don (Ministry of Agriculture and Forestry 2011; Miller and Knowles 1994; Shelbourne et al. 2007). There is significant interest in genetically improving this species to provide diversification of the national planted forest estate away from radiata pine.

Development of powerful clonal propagation methods, such as somatic embryogenesis, has potentially numerous application advantages over conventional rooted cuttings (Bonga 2015). Somatic embryogenesis is considered the main way to achieve true rejuvenation in vegetative propagules because somatic embryos (SEs) develop both embryonic apical and root meristems. Owing to its efficiency in plant regeneration and easy combination with long-term cryopreservation techniques, somatic embryogenesis has become a tool for accelerating clonal testing and deployment (Lelu-Walter et al. 2013). In conifers, advances in somatic embryogenesis over the last 15 years have recently been reviewed (Klimaszewska et al. 2016). The technology is now under development for numerous species and being refined for industrial application in a few important genera such as spruces and pines.

Durzan and Gupta (1987) first reported somatic embryogenesis in Douglas-fir; they achieved somatic embryo development up to the cotyledonary stage. Extensive research to improve this process has been undertaken mainly in the US (Gupta et al. 1995; Taber et al. 1998; Pullman et al. 2003; Pullman et al. 2005, Kong and von Aderkas 2011) and much of this research is still not fully published in scientific journals but has, instead, been patented (Gupta 1996; Gupta and Pullman 1996; Timmis et al. 2011; Kong et al. 2012). In the USA, Weyerhaeuser considers somatic embryogenesis as a core part of their advanced tree improvement strategy for Douglasfir (Dean et al. 2009). Developing improved methods for somatic embryogenesis that are free of patent restrictions would be very helpful for France and New Zealand. Recently, there has been significant progress and simplification with respect to initiation of somatic embryogenesis from immature zygotic embryos (ZEs) of Douglas-fir (initiation frequencies up to 79\%) and proliferation of embryonal masses (EMs). Maltose in the proliferation medium improved both sustained growth of EMs as well as consistently increased the production of early SEs (Reeves et al. in press).

As for other conifers, abscisic acid (ABA) enhances the maturation of Douglas-fir SEs (Durzan and Gupta 1987). In published reports and patents for Douglas-fir, racemic ABA was typically 
Version définitive du manuscrit publié dans / Final version of the manuscript published in : Plant Cell, Tissue and Organ Culture, 2018, 132(1) 137-155

used at quite a low range of 20-70 $\mu \mathrm{M}$ (Gupta 1996; Kong and von Aderkas 2011; Kong et al. 2012). Combined with ABA, a reduction in water availability to the cultured cells was found to enhance SEs quality. Initial methods developed in Douglas-fir included the addition of polyethylene glycol (PEG, Mr 4000) as a high molecular weight solute to the maturation medium (Durzan and Gupta 1987; Gupta et al. 1995; Gupta 1996; Gupta and Timmis 2005). Osmotic stress, through water depletion is viewed as an important signal in directing proper embryo development for high germination vigour and conversion to somatic seedlings in many plant species (von Aderkas and Bonga 2000) including conifers (Klimaszewska et al. 2016). Such a reduction in water availability to the cultured cells can also be achieved by physical means, such as increasing the medium gel strength, to produce cotyledonary, mature SEs with low water content similar to that of seedlings (Klimaszewska et al. 2000; Morel et al. 2014a). Considering our previous experiences with pine (reviewed in Lelu-Walter et al. 2016) and larch species (Lelu-Walter and Pâques 2009; Teyssier et al. 2011), this method was applied to embryogenic lines of Douglas-fir in the current work.

Secondary somatic embryogenesis consists of initiation of embryogenic cultures from a single primary explant, usually a mature, cotyledonary SEs, or explants from older somatic seedlings. Secondary somatic embryogenesis is routinely used with broadleaved tree species as a method of long-term management of productive embryogenic lines (recurrent somatic embryogenesis; Merkle and Cunningham 2011; Isah 2016). However, there are currently few reports of secondary somatic embryogenesis for conifer species and most involve the use of cotyledonary SEs. Secondary somatic embryogenesis was first demonstrated using cotyledonary SEs as the explant in Picea glauca (Eastman et al. 1991) and Larix sp. (Lelu et al. 1994), and later in Abies numidica (Vooková and Kormuták 2006), Pinus pinaster (Klimaszewska et al. 2009) and Picea abies (Uddenberg et al. 2011). Successful initiation of secondary embryogenic cultures and regeneration of secondary somatic plants from older primary somatic seedlings has also been reported for Larix (60-90-day-old somatic plants, Lelu et al. 1994), Picea abies (7-56-day-old to 3-year-old somatic plants, Ruaud 1993; Ruaud et al. 1992; Harvengt et al. 2001), and more recently Picea glauca (up to 10-year-old somatic trees, Klimaszewska et al. 2010). One major possible interest of secondary somatic embryogenesis is to enhance the embryogenic potential of the culture, as first demonstrated for some lines in hybrid larch (Lelu et al. 1994) and maritime pine (Klimaszewska et al. 2009). Secondary somatic embryogenesis was therefore tested in Douglas-fir as a possible way to improve embryogenic potential of initiated lines.

Current maturation protocols lead to the development of cotyledonary SEs that morphologically resemble zygotic embryos (ZEs). SEs are kept in maturation conditions during an arbitrary period before harvesting and subsequent germination. However, such an empirical approach does not provide any information about the quality of SEs with respect to storage compounds. An approach developed in this work, as in other conifers, was to follow the pattern of storage reserve accumulation in cotyledonary SEs during maturation in relation to mature ZEs (LeluWalter et al. 2008; Morel et al. 2014b; Teyssier et al. 2014; von Aderkas et al. 2015).

In this paper we report on a significantly improved procedure for somatic embryogenesis in Douglas-fir, leading to high yield of cotyledonary SEs. Although storage protein accumulation remained lower in cotyledonary SEs, the protein pattern (especially major storage proteins) was similar to reference mature ZEs and somatic plants, displaying seedling-like behaviour after germination and transfer to the nursery. A cytological characterization of EMs is provided for the first time in Douglas-fir. SE development during maturation was enhanced through the use of low EMs density and high gellan gum concentration. Secondary embryogenesis could also be used to improve embryogenic potential of low-productivity genotypes (lines). 


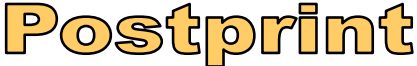

Version définitive du manuscrit publié dans / Final version of the manuscript published in : Plant Cell, Tissue and Organ Culture, 2018, 132(1) 137-155

\section{Materials and methods}

\section{Plant material}

Pseudotsuga menziesii parental trees used in this study were obtained from provenances originating from Washington, either from North Bend (trees 4440, 4455, and 4456) or Enumclaw (trees 4466, 4474, and 4477). The following controlled crosses were performed at INRA, Orléans, France: $4474 \times 4440 ; 4455 \times 4466$, and $4456 \times 4477$. Mature dry seeds (fullsibs, $4474 \times 4440)$ were extracted from the cone scales and cotyledonary zygotic embryos $(\mathrm{ZE})$ were excised from the surrounding megagametophyte. Samples (ZE and megagametophyte) were immediately frozen in liquid nitrogen prior to storage at $-80^{\circ} \mathrm{C}$ for subsequent protein assays.

Initiation of primary embryogenic lines and sustained proliferation of embryonal masses Somatic embryogenesis was induced according to Reeves et al. (in press). Briefly, immature ZEs at the pre-cotyledonary stage were dissected from the megagametophyte and cultured in $90 \mathrm{~mm} \times 16 \mathrm{~mm}$ Petri dishes, containing a modified Litvay medium (Litvay et al. 1985) formulation (Glitz) that has been successfully used for both somatic embryogenesis initiation and EMs proliferation of $P$. radiata (Hargreaves et al. 2009, 2011). Basal Glitz medium was supplemented with $2.3 \mu \mathrm{M}$ 2.4-dichlorophenoxyacetic acid (2,4-D), $2.2 \mu \mathrm{M}$ 6-benzyladenine (BA), $0.087 \mathrm{M}$ sucrose and solidified with $3 \mathrm{~g} \mathrm{~L}^{-1}$ gellan gum (Phytagel ${ }^{\mathrm{TM}}$, Sigma-Aldrich). The resulting EMs were isolated and sub-cultured in clumps every 2 weeks on fresh proliferation medium which consisted of basal Glitz medium supplemented with $4.5 \mu \mathrm{M} 2,4-$ $\mathrm{D}, 2.2 \mu \mathrm{M}$ BA, $0.087 \mathrm{M}$ maltose (instead of sucrose) and solidified with $4 \mathrm{~g} \mathrm{~L}^{-1}$ gellan gum. When necessary, the EMs were cultured as a thin layer dispersed onto a filter paper discs, a method initially developed for pine species (Klimaszewska and Smith 1997; Lelu et al. 1999) to promote cell proliferation. Briefly, proliferating EMs were collected and suspended in 4 to 5 $\mathrm{ml}$ of liquid proliferation medium, vigorously shaken to break up the tissue pieces into a fine suspension (Reeves et al. in press), and poured as a thin layer onto a filter paper (Whatman No 2, diameter $7 \mathrm{~cm}$ ) in a Büchner funnel. A low-pressure pulse was applied to drain the liquid, and then the filter paper with attached cells was placed on the surface of fresh proliferation medium and cultured in darkness at approximatively $23^{\circ} \mathrm{C}$. The EMs density per filter was approximately $300 \mathrm{mg}$ f.m. The $\mathrm{pH}$ of each medium was adjusted to 5.8 before autoclaving. Somatic embryogenesis induction from immature ZEs was performed in 2011 to obtain the SD4 embryogenic line $(4456 \times 4477)$ and in 2012 to obtain embryogenic lines TD1, TD2, TD6, TD13, TD15 $(4474 \times 4440)$ and TD17 (4455 × 4466) $($ Fig.1).

\section{Secondary somatic embryogenesis induction}

Cotyledonary SEs, 6 to 11 weeks old (see maturation section below), from the primary embryogenic lines TD1, TD15, TD17 and SD4 were isolated and transferred to Glitz initiation medium supplemented with either 4.5 or $9.0 \mu \mathrm{M} 2,4-\mathrm{D}, 4.4 \mu \mathrm{M}$ BA, $0.087 \mathrm{M}$ sucrose and solidified with $4 \mathrm{~g} \mathrm{~L}^{-1}$ gellan gum. Each secondary EM, developed from a single SE, was then subcultured as previously described. The primary lines TD1, TD15, TD17 and SD4 gave rise to secondary embryogenic lines (TD1-2; TD15-1, TD15-2; TD17-3; SD4-1, SD4-4, and SD47 respectively, Fig.1).

\section{Histological-cytological observations during the proliferation phase}

The viability of early SEs was evaluated and the histology of the EMs was examined. Viability of the SEs was determined by double staining with fluorescein diacetate (FDA; Sigma-Aldrich, Germany) and propidium iodide (PI; Sigma-Aldrich, Germany) as described by Cvikrová et al. (2016). The EMs were re-suspended in liquid proliferation medium and stained with $2.25 \mu \mathrm{M}$ PI. An equal volume of $0.02 \%(\mathrm{v} / \mathrm{v})$ FDA was then added. Stained early SEs were observed within 5 minutes under a confocal laser-scanning microscope (Zeiss LSM 5 Duo, Germany) 
Version définitive du manuscrit publié dans / Final version of the manuscript published in :

Plant Cell, Tissue and Organ Culture, 2018, 132(1) 137-155

http://dx.doi.org/10.1007/s11240-017-1318-0

using the following two filter sets: i) excitation of fluorescein in viable cells at $488 \mathrm{~nm}$ by an Argon/2 laser, emission filter set LP 505-550; ii) excitation of PI in dead cells at $561 \mathrm{~nm}$ by DPSS laser, emission filter set LP 650. Paraffin sections of EMs were prepared for histological observation as described by Vondráková et al. (2015). Briefly, samples were fixed with 50\% FAA (formaldehyde/acetic acid/ethanol/water 1/1/9/9, v/v/v/v) for $24 \mathrm{~h}$, gradually dehydrated in an ethanol/ butanol series and infiltrated with paraffin wax. Sections $(12 \mu \mathrm{m})$ were stained with $0.1 \%(\mathrm{w} / \mathrm{v})$ Alcian blue (Sigma-Aldrich, Germany) in 3\% acetic acid and $0.1 \%(\mathrm{w} / \mathrm{v})$ Nuclear Fast Red (in 5\% $\mathrm{Al}_{2}\left(\mathrm{SO}_{4}\right)_{3}$ as described by Beneš and Kamínek (1973). Preparations were examined using a Zeiss Jenaval transmission light microscope. Images were recorded using a Nikon DS-5M digital camera and processed using the Nis-Elements AR 3.2 (Laboratory Imaging, Prague, Czech Republic) image analysis system.

\section{Maturation conditions}

Maturation experiments were conducted with both primary embryogenic lines initiated from immature ZEs and secondary embryogenic lines initiated from cotyledonary SEs. Proliferating EMs collected from filter papers were weighed, dispersed in liquid Glitz medium without plant growth regulators and distributed onto a filter paper disc placed on the surface of Glitz maturation medium supplemented with $0.2 \mathrm{M}$ sucrose and various cis-trans $( \pm)$-abscisic acid (ABA) and gellan gum concentrations (see below). Maturation was conducted in darkness at approximatively $23^{\circ} \mathrm{C}$. The number of mature cotyledonary SEs produced after 8 weeks was counted in each of the Petri dishes and the embryogenic potential (number of SEs per $\mathrm{g}$ f.m.) was estimated. The number of shooty embryos (abnormal, greenish SEs, with elongated cotyledons) was also recorded.

\section{Preliminary experiments}

Preliminary maturation experiments were conducted to determine factors promoting recovery of cotyledonary SEs. Based on our previous results in different conifer species, gellan gum concentrations and ABA appeared to be critical factors. In addition, we considered EMs density per filter as a potential factor affecting EMs proliferation during maturation and ultimately maturation yield. A first preliminary experiment was conducted with five embryogenic lines (TD1, TD2, TD6, TD15 and SD4). We tested two gellan gum concentrations (6 or $8 \mathrm{~g} \mathrm{~L}^{-1}$ ) and three EMs densities per filter $(50,100$ or $200 \mathrm{mg}$ f.m.). There were five Petri dishes per treatment (150 Petri dishes overall). A second preliminary experiment was conducted with two embryogenic lines (TD1 and TD15). We tested three gellan gum concentrations $\left(6,8\right.$ or $10 \mathrm{~g} \mathrm{~L}^{-}$ ${ }^{1}$ ), two EMs densities per filter (50 or $100 \mathrm{mg}$ f.m.) and two ABA concentrations (60 or $\left.80 \mu \mathrm{M}\right)$. There were five Petri dishes per treatment (100 Petri dishes overall).

\section{Experiment 1: cell density and gellan gum concentrations}

Following these preliminary experiments, the effects of gellan gum concentrations (8 or $10 \mathrm{~g}$ $\mathrm{L}^{-1}$ ) and cell density per filter ( $50 \mathrm{or} 100 \mathrm{mg}$ f.m.) on recovery of cotyledonary SEs were further assessed. Experiments were carried out with all seven lines available (TD1, TD2, TD6, TD13, TD15, TD17 and SD4). There were 5-6 Petri dishes per treatment and experiments were repeated twice (302 Petri dishes overall).

\section{Experiment 2: maturation of secondary embryogenic lines vs primary lines}

EMs from primary (TD1, TD15, TD17 and SD4) and secondary lines (TD1-2; TD15-1, TD152; TD17-3; SD4-1, SD4-4, and SD4-7) were matured on Glitz maturation medium supplemented with $0.2 \mathrm{M}$ sucrose, $60 \mu \mathrm{M}$ ABA and $10 \mathrm{~g} \mathrm{~L}^{-1}$ gellan gum at a cell density of 50 mg f.m. per filter. There were 5-6 Petri dishes per cell line and experiments were repeated three times (187 Petri dishes overall).

\section{Conversion of somatic embryos to plants}


Version définitive du manuscrit publié dans / Final version of the manuscript published in : Plant Cell, Tissue and Organ Culture, 2018, 132(1) 137-155

Cotyledonary SEs were removed from the maturation medium and placed horizontally, all in the same orientation, on the surface of germination medium, i.e. a Glitz medium without plant growth regulators, supplemented with $0.087 \mathrm{M}$ sucrose and $4 \mathrm{~g} \mathrm{~L}^{-1}$ gellan gum. In the germination phase, there were 5-15 SEs per Petri dish. The Petri dishes were tilted at an angle of approximately $35^{\circ}-40^{\circ}$ and placed in darkness for one week to promote hypocotyl elongation and reduce anthocyanin accumulation. SEs were then exposed to a 16-h photoperiod $(10 \mu \mathrm{mol}$ $\mathrm{m}^{-2} \mathrm{~s}^{-1}$ ) at $23 / 20^{\circ} \mathrm{C}$ day/night temperatures. The SEs were considered fully germinated as soon as their radicle emerged. Germinated SEs were considered to have become plantlets as soon as their epicotyl was developed with primary needle elongation. Germination and plantlet recovery were assessed after 4 and 10 weeks, respectively. The plantlets were subcultured once onto fresh germination medium of the same formulation after 6-7 weeks.

Effect of the maturation duration on both germination and plantlet recovery was assessed for the lines TD1, TD13 and TD15. Cotyledonary SEs were harvested after 5, 6, 7 and 8 weeks of maturation. The number of Petri dishes varied from 6 to 10 (86 Petri dishes overall).

The effect of the presence of activated charcoal (AC) in the germination medium on germination and plantlet frequencies was assessed for lines TD1, TD2, TD6 and TD15. Cotyledonary SEs 5-6 weeks old were transferred to germination medium with or without $10 \mathrm{~g}$ $\mathrm{L}^{-1} \mathrm{AC}$. The number of Petri dishes varied from 3 to 10 per treatment (46 Petri dishes overall).

\section{Determination of total protein content}

To determine whether maturation duration was associated with varying levels of storage reserve in SEs, total proteins were extracted and quantified. Cotyledonary SEs of lines TD1 and TD15 matured on medium containing $0.2 \mathrm{M}$ sucrose, $60 \mu \mathrm{M} \mathrm{ABA}$ and $10 \mathrm{~g} \mathrm{~L}^{-1}$ gellan gum, were collected after 5, 6, 7 and 8 weeks of culturing. Their protein content was compared with those of mature ZEs from the same family (dry seeds, $4474 \times 4440$ ). Methods for total protein extraction, electrophoresis and quantification in ZEs and SEs are described in Teyssier et al. (2011). Briefly, SEs (20 mg f.m.) or ZEs (10 mg f.m.) were ground in liquid nitrogen, homogenized with $0.5 \mathrm{~mL}$ of lysis buffer $(10 \%(\mathrm{v} / \mathrm{v})$ glycerol; $2 \%(\mathrm{w} / \mathrm{v}) \mathrm{SDS} ; 5 \%(\mathrm{v} / \mathrm{v}) \beta-$ mercapto-ethanol; $2 \%$ (w/v) poly(vinyl) polypyrrolidone; $50 \mathrm{mM}$ Tris $\mathrm{pH} 6.8$ ). The samples were incubated for $5 \mathrm{~min}$ at $95^{\circ} \mathrm{C}$, and extracted twice. Protein concentrations were assessed using Bradford assays in which BSA (Bovine Serum Albumin) was the standard.

\section{Gel electrophoresis for protein separation}

Extracted total proteins were separated by sodium dodecyl sulphate-polyacrylamide gel electrophoresis (SDS-PAGE) $(12 \%)$ with stacking gel (4\%) following standard protocols. The gel was stained for proteins with colloidal Coomassie Brilliant Blue G-250 (CBB-G). The main protein bands observed for SEs (7 weeks maturation), ZEs and megagametophyte were cut from a $12 \%$ gel and subjected to LC-MS/MS identification.

\section{Protein identification by mass spectrometry}

Gel pieces were destained and digested in-gel using trypsin. The peptide mixture was analysed on an Ultimate 3000 nanoLC system (C18 PepMapTM trap column; Dionex, Amsterdam, The Netherlands) coupled to a LTQ-Orbitrap XL mass spectrometer (ThermoFinnigan, San Jose, CA). Data were acquired using Xcalibur 2.1 software in a data-dependent mode. Data were searched by SEQUEST through Proteome Discoverer 1.4 (Thermo Fisher Scientific Inc.) against a database dedicated to Pseudotsuga menziesii (54795 entries, August 2016, http://pinegenome.org/pinerefseq/). Spectra from peptides higher than 5000 Da or lower than $350 \mathrm{Da}$ were rejected. The search parameters were as follows: mass accuracy of the monoisotopic peptide precursor and peptide fragments was set to $10 \mathrm{ppm}$ and $0.6 \mathrm{Da}$ respectively. Only $b$ - and y-ions were considered for mass calculation. Oxidation of methionines $(+16 \mathrm{Da})$ was considered as variable modification and carbamidomethylation of cysteines $(+57 \mathrm{Da})$ as fixed modification. Two missed trypsin cleavages were allowed. Peptide 
Version définitive du manuscrit publié dans / Final version of the manuscript published in : Plant Cell, Tissue and Organ Culture, 2018, 132(1) 137-155

validation was performed using the Percolator algorithm (Käll et al. 2007) and only "high confidence" peptides were retained corresponding to a 1\% False Positive Rate at peptide level.

\section{Acclimatization of somatic plants}

After 14-16 weeks on germination medium, plantlets were transplanted to Dalton's cutting mix containing $40 \%$ bark fibre medium screened, $20 \%$ perlite C4, $20 \%$ pumice sand and $20 \%$ peat. Plantlets were placed in a nursery propagation house with a humidity set point of $90-95 \%$, air conditioning set at $20^{\circ} \mathrm{C}$, fan venting set at $25^{\circ} \mathrm{C}$, bench heating of $18-22^{\circ} \mathrm{C}$ and a $16 \mathrm{hr}$ photoperiod. After approximately 2 months, plantlets were moved to a lower humidity environment (75\%) with no bench heating or photoperiod. The humidity was reduced to the ambient level over a 3-4 week period before moving the plants to a shade house for the final stage of hardening-off prior to planting in the field.

\section{Statistical analysis}

Qualitative data for the study of factors influencing maturation of SE was analysed with the R package breedR (Muñoz and Sanchez 2015). Mixed models were fitted involving genotypic lines, cell density per filter, gellan gum and ABA concentrations as the main fixed effects. Fixed effect estimates and their corresponding standard errors were subsequently obtained to complement the boxplots. Count data from experiment 2 and conversion of SE to plants were analysed with multiple chi-squared tests against ad-hoc randomized distributions out of 3000 permutations of the data (R Core Team 2016).

For the protein data, statistical analysis was carried out with the R software (version 0.99.903; (C) 2009-2016 RStudio, Inc.). Variations in total protein content during maturation were analysed by ANOVA and with multiple comparisons of means with Tukey contrasts $(p<0.05)$.

\section{Results}

\section{Histological-cytological description of Douglas-fir EMs}

The EMs of Douglas-fir consist of different types of early SEs. The most typical structure is a huge polyembryogenic centre (Figs 2a, 3a). Its broad meristem creates a compact cell "package" together with the suspensor part. Suspensor cells which are directly connected to meristematic cells or within a few rows beneath the meristem are alive, usually narrow and tightly interconnected (Figs 2d, 3b, c). Further from the meristem and inside the cell "package", suspensor cells are loosely-joined by a mucilaginous extracellular matrix (Figs 2a, c, e) and these cells are very often dead (Figs 3a, c). The cell "package" of the polyembryogenic centre terminates in disintegrated material consisting of the remains of dead suspensor cells (note the lower part of Figs $2 a$ and 3a, and the left side of Fig. 3b). This material creates an anchor which connects the polyembryonic centre with the clump of the EMs. Besides the huge polyembryogenic centres $(800-1500 \mu \mathrm{m}$, measured as the diameter of the cross section), smaller ones ( $400-700 \mu \mathrm{m})$ were also observed (Figs 2c, 3b) as well as isolated embryos with one large embryonal head $(300-400 \mu \mathrm{m})$ and a long tightly arranged suspensor (Figs $2 \mathrm{~b}, 3 \mathrm{c}$ ). Suspensor cells within the mass of these long suspensors are stuck together by a mucilaginous extracellular matrix (Supplementary data 1). New, very small embryos consisting of several layers of meristematic cells and a few loosely arranged suspensor cells $(100-250 \mu \mathrm{m}$ and smaller) occurred usually beside the disintegrated dead mass of the polyembryogenic centres (Fig. 3c).

\section{Factors influencing maturation of SEs}

After five weeks of maturation, SEs reached the cotyledonary stage. After eight weeks of maturation, there were two major and distinct morphological features among the cotyledonary SEs. The first SEs morphotype had elongated hypocotyl and cotyledons surrounding the apical 
Version définitive du manuscrit publié dans / Final version of the manuscript published in : Plant Cell, Tissue and Organ Culture, 2018, 132(1) 137-155

meristem, with a general yellowish colour and only a few embryos turning a greenish colour. These SEs were classed as of high morphological quality (Fig. 4a) similar to the reference ZEs. The second major SEs morphotype exhibited abnormal morphologies, in particular a short hypocotyl and cotyledons (Fig. 4b). These "shooty" embryos were generally greenish in colour and were considered to be poorly developed. Our objective was to determine cultural conditions promoting development of high quality cotyledonary SEs while reducing the number of shooty ones.

\section{Preliminary experiments}

The objective of these preliminary maturation experiments was to identify factors promoting recovery of cotyledonary SEs. From the first experiment, it appeared that gellan gum concentration had a significant effect $(p=4.118 \mathrm{e}-10)$ on SEs production. Embryogenic potential was estimated to a mean of 40 cotyledonary SEs $\mathrm{g}^{-1} \mathrm{f}$.m. on medium with $6 \mathrm{~g} \mathrm{~L}^{-1}$ gellan gum and $178 \mathrm{SEs} \mathrm{g}^{-1}$ f.m. with $8 \mathrm{~g} \mathrm{~L}^{-1}$ gellan gum (Supplementary data 2). Increasing EMs density per filter paper disc similarly affected maturation yield and resulted in a significant decrease $(p$ $=3.16 \mathrm{e}-13$ ) in yield of high quality SEs, although this effect was somewhat less important than that of gellan gum concentration (Supplementary data 2). On average 195, 81 and $51 \mathrm{SEs} \mathrm{g}^{-1}$ f.m. were obtained for 50, 100 and $200 \mathrm{mg}$ f.m. EMs per filter, respectively. Mean cotyledonary SEs production was also highly variable among lines from those with low embryogenic potential, as expressed by TD6 (133 SEs $\mathrm{g}^{-1} \mathrm{f} . \mathrm{m}$.), to high embryogenic potential in the case of

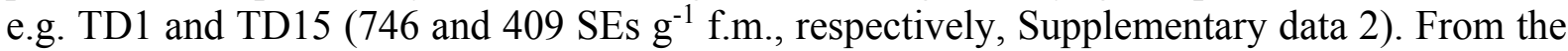
second preliminary experiment, it appeared that ABA had no significant effect on development of cotyledonary SEs at the tested concentrations. On average, embryogenic potential was estimated to be 431 and 590 SEs g $^{-1}$ f.m. with 60 and $80 \mu \mathrm{M} \mathrm{ABA}$, respectively (Supplementary data 3). Again, gellan gum concentration had a significant, strong effect on SEs production. Embryogenic potential was estimated to a mean of only 148 cotyledonary SEs $\mathrm{g}^{-1}$ f.m. on medium with $6 \mathrm{~g} \mathrm{~L}^{-1}$ gellan gum and 411 and $745 \mathrm{SEs} \mathrm{g}^{-1}$ f.m. with 8 and $10 \mathrm{~g} \mathrm{~L}^{-1}$ gellan gum, respectively (Supplementary data 3A). Concomitantly, the yield in terms of abnormal, shooty embryos significantly decreased as gellan gum concentration increased, varying from 315 shooty embryos $\mathrm{g}^{-1}$ f.m. $\left(6 \mathrm{~g} \mathrm{~L}^{-1}\right.$ gellan gum $)$ to $219\left(8 \mathrm{~g} \mathrm{~L}^{-1}\right)$ and $85\left(10 \mathrm{~g} \mathrm{~L}^{-1}\right)$ (Supplementary data $3 b)$. Interestingly, EM proliferation was apparently reduced when high gellan gum concentration was used $\left(8\right.$ or $\left.10 \mathrm{~g} \mathrm{~L}^{-1}\right)$.

\section{Experiment 1: effect of cell density and gellan gum concentrations}

Preliminary experiments helped us with the design of larger maturation experiments involving all available embryogenic lines (TD1, TD2, TD6, TD13, TD15, TD17, SD4). We kept ABA at the lowest concentration $(60 \mu \mathrm{M})$ and we chose to test further the highest gellan gum treatments (8 or $10 \mathrm{~g} \mathrm{~L}^{-1}$ ) and the lowest cell densities (50 or $100 \mathrm{mg}$ f.m. EM per filter).

Mean SEs production significantly varied $(p=2.2 \mathrm{e}-16)$ between the lines, as expected from the preliminary experiments, with embryogenic potential estimated to be low for TD2, TD6, TD17 (mean ranging from 27 to $61 \mathrm{SEs} \mathrm{g}^{-1}$ f.m.), moderate in the cases of SD4 and TD13 (108 and 455 SEs g $^{-1}$ f.m., respectively) and high for lines TD1 and TD15 (860 and 1544 SEs $^{-1}$ f.m., respectively, Fig. 5a). The ranking was stable between experiments, although significant variation was observed. Increasing gellan gum concentration was confirmed to improve the recovery of cotyledonary SEs significantly $(p=6.09 \mathrm{e}-7)$ with concomitant and significant reduction in the number of shooty embryos (Fig. 5b). This effect is particularly remarkable for embryogenic lines with poor or moderate capacity for SEs production. For example for $50 \mathrm{mg}$ f.m. EMs per filter, SD4 yielded 5 times more cotyledonary SEs with $10 \mathrm{~g} \mathrm{~L}^{-1}$ instead of $8 \mathrm{~g} \mathrm{~L}^{-}$ ${ }^{1}$ gellan gum (108 and 20 SEs g $^{-1}$ f.m., respectively); for $100 \mathrm{mg}$ f.m. EMs per filter, SD4 yielded 16 times more cotyledonary SEs with $10 \mathrm{~g} \mathrm{~L}^{-1}$ instead of $8 \mathrm{~g} \mathrm{~L}^{-1}$ gellan gum (58.7 and 3.5 SEs $\mathrm{g}^{-1}$ f.m., respectively, Fig. 5a). Finally, it was also confirmed during this experiment that 
Version définitive du manuscrit publié dans / Final version of the manuscript published in :

Plant Cell, Tissue and Organ Culture, 2018, 132(1) 137-155

http://dx.doi.org/10.1007/s11240-017-1318-0

reducing cell density to $50 \mathrm{mg}$ f.m. per filter slightly improved cotyledonary SE recovery in most lines (Fig. 5a).

\section{Experiment 2: embryogenic potential of primary and secondary embryogenic lines}

After three weeks of induction, secondary $\left(2^{\mathrm{ry}}\right)$ somatic embryogenesis was initiated from cotyledonary SEs and EMs became easily detectable after four weeks of culturing. Embryonal mass developed at the base of the hypocotyl region, above the embryonal root cap (Fig. 1). Cotyledonary SEs from lines TD1, TD15, TD17 and SD4 all produced $2^{\mathrm{ry}}$ EM (Table 1). Successful induction of $2^{\text {ry }}$ somatic embryogenesis was quantified as the percentage of SEs developing EM. There was no significant difference between the two 2,4-D concentrations tested $(4.5 v s 9.0 \mu \mathrm{M})$. In contrast, a significant genotype effect was detected (Table 1). The highest response was obtained for line SD4 (overall $25.3 \%$ of SEs produced $2^{\text {ry }}$ EM). The response of other lines to the induction treatment was significantly lower, with overall initiation rates in the range $4.4-8.7 \%$ (Table 1). Once obtained, $2^{\text {ry }}$ EMs were easily proliferated in the same conditions as primary EMs.

Maturation experiments were then performed in order to compare embryogenic potential of primary and secondary EMs. As previously reported, the observed variation in mean SEs production is again significant among the primary lines. TD1 and TD15 were confirmed to be highly embryogenic (means of 1744 and 1659 SEs g $^{-1}$ f.m., respectively), followed by SD4 (478 $\mathrm{g}^{-1}$ SEs f.m.) whereas TD17 exhibited very low embryogenic potential $\left(30 \mathrm{~g}^{-1}\right.$ SEs f.m.) (Table 2). Maturation yield of primary and secondary lines from the highly productive genotypes TD1 and TD15 were similarly very high, although some significant decrease was observed in the case of TD15 $2^{\text {ry }}$ lines (Fig. 6). Interestingly, $2^{\text {ry }}$ lines of the more recalcitrant genotypes TD17 and SD4 were significantly more productive than corresponding primary lines (Fig. 6). TD173 yielded five times more cotyledonary SEs than the original TD17 primary line. SD4-1, SD44 and SD4-7 yielded two to three times more cotyledonary SEs than SD4 (Table 2). From these results, it appears that no significant gain could be obtained with an additional cycle when embryonic potential is already high during the first cycle (TD1, TD15). In contrast, for recalcitrant genotypes with low embryonic potential (SD4 and TD17), there are advantages in going through an additional cycle of somatic embryogenesis initiation.

\section{Conversion of somatic embryos to plants}

Yellowish cotyledonary SEs of a morphologically high standard were harvested from primary lines TD1, TD13 and TD15 after 5, 6, 7 or 8 weeks maturation and immediately transferred onto germination medium. Germination took place rapidly, with SEs turning green and both hypocotyls and cotyledons starting to elongate during the 1-week germination period in the dark. SEs were fully rooted within 2-3 weeks in light conditions and, remarkably, root growth was characterized by a rapid elongation on the surface of the germination medium (Fig. 7 a). Development of the epicotyl and primary needles then happened within 5-6 weeks. Only germinated SEs that developed epicotyls were considered to have become plantlets (Fig. 7 b). The effect of maturation duration on SEs germination and conversion to plantlets was assessed. There was no significant effect on germination frequency. For the three lines tested, germination rates remained similarly high for SEs matured for 5, 6, 7 and 8 weeks $(97-100 \%$, Table 3). In contrast, conversion frequency of cotyledonary SEs into plantlets was significantly affected by the maturation duration $(\chi 2=59.83, p=0.0004)$, with the highest frequencies (91$98 \%$ ) obtained when SEs were matured for only 5 weeks. Prolonging the maturation treatment for 1-3 more weeks resulted in a significant reduction in SEs conversion rates (53-89\%).

The presence of AC in the germination medium was tested for 4 lines (TD1, TD2, TD6, TD15). No significant effect could be detected with respect to either germination or plantlet frequencies (Supplementary data 4). After 4 weeks, no significant differences were found between genotypes for germination, which remained similarly high for all lines tested $(93-100 \%$ Supplementary data 4). For plantlet frequencies, significant differences were found between 
Version définitive du manuscrit publié dans / Final version of the manuscript published in :

Plant Cell, Tissue and Organ Culture, 2018, 132(1) 137-155

http://dx.doi.org/10.1007/s11240-017-1318-0

genotypes, with TD1 showing greater success and TD6 and TD2 the worst performances. Lines TD1 and TD15 exhibited similar conversion rates, as previously reported (Table 3).

Plantlets were acclimatized, as described in the materials and methods section, in nursery propagation conditions and shade houses. Approximately 6 months after transfer to ex vitro conditions (Fig. 7c) plantlet survival in the shade house ranged from 39 to $100 \%$ depending on the genotype (data not shown). A sample of the surviving plantlets was transferred to a nursery bed where they are currently growing (Fig. 7d).

\section{Protein analysis in cotyledonary somatic embryos}

To estimate the pattern of protein accumulation in embryos as a function of maturation duration (5-8 weeks), the total protein content was estimated in SEs from 2 lines (TD1 and TD15) using the Bradford assay. The maturation duration had an important effect on total protein content (ANOVA, $P<4.16 .10^{-13}$ ), which was found to increase gradually from 5 to up to 7 weeks of maturation in both lines. The maximum value was in the range $120-150 \mu \mathrm{g} \mathrm{mg}^{-1} \mathrm{f}$.m. depending on the genotype (Table 4). It was much lower than the protein content observed in reference, cotyledonary ZEs (ca. $300 \mu \mathrm{g} \mathrm{mg}^{-1}$ f.m.) as well as megagametophyte (ca. $550 \mu \mathrm{g} \mathrm{mg}^{-1}$ f.m.). Total protein extracts were analysed after separation through SDS-PAGE electrophoresis (Fig. 8). Protein extracts from ZEs and megagametophyte excised from dry seeds were loaded as controls. The protein pattern changed markedly as a function of maturation duration with, in particular, accumulation of a few major bands after 7 and 8 weeks. They were not detectable in green 8-week-old SEs. The electrophoretic migration of these bands was similar to that observed for protein extracts from ZEs and megagametophyte. The protein content of these major bands was analysed using mass spectrometry for SEs matured for 7 weeks and in ZEs and megagametophyte. They were identified as two storage proteins, namely $7 \mathrm{~S}$-vilicin-like and legumin-like proteins (Table 5). The latter is an isoform of the 11S-globulin-like protein.

\section{Discussion}

\section{Embryonal masses of Douglas-fir: histo-cytological characterization}

In this work we propagated EMs of Douglas-fir using modified Glitz medium formulations (Reeves et al. in press), which was selected as the most suitable for the sustained growth. Refinements reported by Reeves et al. (in press) included the use of maltose as the preferred carbon and energy source during proliferation. It has been reported for a number of species, including Douglas-fir (Gupta 1996; Reeves et al. in press), that maltose promotes SEs proliferation.

On this medium, Douglas-fir EMs were composed of compact polyembryogenic centres (400$1500 \mu \mathrm{m}$ in cross section) tightly joined to a few rows of live suspensor cells, themselves connected to loosely-aggregated material mostly composed of dead suspensor cells and a mucilaginous extracellular matrix. This disintegrated mass of cells apparently anchored the polyembryogenic centre within EMs clumps. Polyembryogenic centres have also been observed in embryogenic cultures of other conifer species during proliferation, e.g. Picea abies (Vondráková et al. 2010) and Abies alba (Vondráková et al. 2011). Nevertheless, polyembryogenic centres of Picea abies are usually smaller, dense suspensors consisting of cells that are tightly connected in the proximity of the embryonal heads but loosely arranged in the distal part of suspensor where the single, usually already dying cells, are released. Robust, long and very compact suspensors are usually characteristic of the polyembryogenic centres of Abies alba. The main difference between Douglas-fir and Norway spruce or Silver fir is the presence of dead and disintegrated cell material as an integral part of the polyembryogenic centres in Douglas-fir embryogenic culture. Singulated, well-developed early embryos (of up to $400 \mu \mathrm{m}$ in diameter) may resemble SEs of Abies alba (Vondráková et al. 2011) at an early 
Version définitive du manuscrit publié dans / Final version of the manuscript published in : Plant Cell, Tissue and Organ Culture, 2018, 132(1) 137-155

stage of maturation. The compact well-arranged suspensors of this species consist of long cells that are tightly connected to each other. In contrast, cells of the quite robust suspensors of Douglas-fir SEs are tightly joined together on the external surface but the cells are loosely arranged inside the suspensor and are connected mostly by a mucilaginous extracellular matrix. We previously observed that particularly well-developed and singulated Douglas-fir early embryos with large embryonal heads were frequent on Glitz proliferation medium containing maltose (Reeves et al. in press). Smaller embryos (less than 100-250 $\mu \mathrm{m}$ ) with usually very active meristematic cells were also observed within the disintegrated mass of dead cells connected to polyembryogenic centres.

Large polyembryogenic centres can be interpreted as resulting from continuous but incomplete cleavage polyembryony of proembryonal tube cells and/or "budding" (somatic polyembryogenesis) of the original zygotic embryonal-suspensor mass used for initiation (Hong et al. 1992). In contrast, singulated early SEs may result from either complete cleavage polyembryogeny or an indirect process involving cellular dedifferentiation and redifferentiation, i.e. somatic embryogenesis (Durzan and Gupta 1987; Hong et al. 1992). Our observations suggested that de novo somatic embryogenesis could occur within the disintegrated mass of suspensor cells through dedifferentiation of a cell. Gupta and Pullman (1996) similarly reported that, in Douglas-fir, frequent and tightly aggregated early stage embryos are interspersed with individual (singulated), well-developed early embryos suggesting again that EM could develop directly or indirectly through somatic polyembryogenesis or somatic embryogenesis. These authors also reported that somatic polyembryogenesis could result in clumped embryos which could remain united and difficult to convert into singulated cotyledonary SEs. High ABA levels negatively affected polyembryogeny in conifers and promote development of bipolar individual SEs (Hong et al. 1992; Gupta and Pullman 1996). In the best experimental conditions, early SEs matured at high rate in some lines (> 1000 cotyledonary SEs $\mathrm{g}^{-1}$ f.m.), suggesting that cleavage polyembryony is somewhat inhibited by the high exogenous $\mathrm{ABA}$ levels provided in the maturation medium.

\section{Impaired embryo development in "recalcitrant" genotypes}

Embryogenic potential of both primary and secondary embryogenic lines was strongly affected by the genotype of the primary embryogenic line, a recurrent phenomenon previously reported in Douglas-fir (Gupta et al. 1995) and in virtually all conifer species (reviewed in Klimaszewska et al. 2016). All 7 tested lines (from 3 families) produced cotyledonary SEs under improved maturation conditions. However, although mean maturation yield across tested primary lines was high (467 SEs $\mathrm{g}^{-1} \mathrm{f} . \mathrm{m}$.), huge variation between lines was observed from a low of $30 \mathrm{SEs}$ $\mathrm{g}^{-1}$ f.m. (TD17) up to $1744 \mathrm{SEs}^{-1}$ f.m. (TD1). A similar variation was observed with secondary lines, with maturation yield in the range of 148 (TD17-3) to 2069 (TD1-2) SEs $\mathrm{g}^{-1}$ f.m. Maturation ability of any single genotype may be determined by a particular state of active gene expression and associated processes at the developmental stages and transitions from early to late embryogenesis in conifers (reviewed in Trontin et al. 2016a). A number of key genes and processes are likely to be involved in epigenetic regulation as well as tolerance and response to various stresses (Miguel et al. 2016). Genotype recalcitrance to any maturation treatment may, therefore, not only result from unfavourable genetic background but also from inappropriate environmental conditions and physiological state of the EMs culture.

\section{Environmental conditions affecting SEs development: the significant effect of high gellan gum concentration and low cell density}

Our objective was to identify major factors promoting normal cotyledonary SEs development in Douglas-fir. We considered key general issues already identified for other conifers (Klimaszewska et al. 2016; Lelu-Walter et al. 2016) such as i) ABA and ii) gellan gum 
Version définitive du manuscrit publié dans / Final version of the manuscript published in : Plant Cell, Tissue and Organ Culture, 2018, 132(1) 137-155

concentrations in maturation medium as well as iii) cell density on the selected support (filter paper). Cotyledonary SEs development was first reported in Douglas-Fir about 30 years ago by Durzan and Gupta (1987). These authors had already demonstrated the beneficial effect of ABA (at low concentration: $0.5 \mu \mathrm{M}$ ) to control somatic polyembrony (inhibition of cleavage polyembryony) and to promote individual SEs development in cell suspension cultures. In our experiments we did not detect any significant effect of ABA in the range 60-80 $\mu \mathrm{M}$, which is the typical ABA concentration effective in many conifers (Klimaszewska et al. 2016). In the present protocol, ABA was used at the lower concentration tested $(60 \mu \mathrm{M})$ as high ABA levels for long periods can also increase the frequency of developmentally abnormal embryos (Kong et al. 2012).

SEs maturation was significantly enhanced by increasing the gellan gum concentration from 6 to $10 \mathrm{~g} \mathrm{~L}^{-1}$. If the positive effect of high gellan gum has been well described in pines and larches (reviewed in Lelu-Walter et al. 2016; Teyssier et al. 2011), this is the first report demonstrating its value for Douglas-fir. Interestingly, Kong and von Aderkas (2011) used $8 \mathrm{~g} \mathrm{~L}^{-1}$ gellan gum in a pretreatment maturation medium for inducing cryotolerance of immature SEs in Douglasfir. Increasing the gellan gum from 6 to $10 \mathrm{~g} \mathrm{~L}^{-1}$ not only significantly improved cotyledonary SEs yield but also SEs morphological behaviour. In addition, EMs proliferation appeared to be reduced together with cells exhibiting a dried appearance on maturation medium with high gellan gum. Over-proliferation of cell/EMs during the maturation step in Pinus pinaster has been suggested to have antagonistic effects on SEs development (Morel et al. 2014a). Using the highest gellan gum concentrations tested ( 8 and $10 \mathrm{~g} \mathrm{~L}^{-1}$ gellan gum), most SEs were wellshaped with elongated hypocotyls and cotyledons. In such improved maturation conditions (compared with $6 \mathrm{~g} \mathrm{~L}^{-1}$ gellan gum), a reduced frequency of abnormal, "shooty" embryos (short hypocotyl and cotyledons) was concomitantly observed. Abnormal SEs development and/or quality (low ability for conversion into plantlets) is a critical problem that has been previously reported in Douglas-fir as well as in other conifers following various maturation treatments such as different ABA or carbohydrate contents (e.g. Kong et al. 2012; Gupta and Timmis 2005). In Picea abies and Pinus sylvestris, abnormal SEs development (i.e., malformed, aborted and/or fused cotyledons) has been reported (Hakman et al. 2009; Abrahamsson et al. 2012). It has been suggested that the resulting high frequency of supernumerary suspensor cells in early SEs promoted abnormal SEs development. This degeneration pattern could take place very early in the induction phase when somatic embryogenesis is established from immature ZEs at the cleavage polyembryony stage (Abrahamsson et al. 2017). Obviously, this was not the case in Douglas-fir during our experiments since we were able to reduce significantly the frequency of abnormal SEs using high gellan gum during maturation. In the tested conditions, the yield of abnormal shooty embryos decreased from ca. $350-420 \mathrm{SEs} \mathrm{g}^{-1}$ f.m. $\left(6 \mathrm{~g} \mathrm{~L}^{-1}\right)$ to $150-300 \mathrm{SEs} \mathrm{g}^{-}$ ${ }^{1}\left(8 \mathrm{~g} \mathrm{~L}^{-1}\right)$ and less than $100 \mathrm{SEs} \mathrm{g}^{-1}\left(10 \mathrm{~g} \mathrm{~L}^{-1}\right)$.

Besides a significant gellan gum concentration effect, cell density also had a significant impact on maturation yield and quality of cotyledonary SEs, although this effect was less important than that observed for gellan gum concentration. Reducing the cell density to $50 \mathrm{mg}$ f.m. per filter significantly reduced the frequency of abnormal shooty cotyledonary embryos, concomitantly increasing the yield of normal cotyledonary SEs. We previously showed that EMs proliferation appeared to be reduced on high gellan gum maturation medium. The effect of low water availability as a culture constraint to activate ABA-mediated molecular and physiological responses to promote embryo development (Morel et al. 2014a) could be even more important when EMs are plated at low density, in a more uniform cell layer. Plating cells in a thin layer is thought to increase the likelihood that most cells are exposed to the physical and chemical conditions necessary for maturation.

\section{Secondary somatic embryogenesis from cotyledonary SEs as a way to improve maturation ability of low-performance embryogenic lines}


Version définitive du manuscrit publié dans / Final version of the manuscript published in : Plant Cell, Tissue and Organ Culture, 2018, 132(1) 137-155

The success of somatic embryogenesis typically rapidly declines in conifer species with age and/or phase-change related effects (Klimaszewska et al. 2016; Trontin et al. 2016b). Using cotyledonary SEs, a high induction frequency of EMs has been obtained in Larix $\times$ leptoeuropaea ( $98 \%$, Saly et al. 2002), as well as in maritime pine (13.6-81.8\%, Klimaszewska et al. 2009), whereas comparatively low rates have been obtained in Abies numidica (5.5-9.0\%, Vooková and Kormuták 2006). In this work, we initiated secondary somatic embryogenesis from cotyledonary SEs in Douglas-fir. All tested genotypes responded to the initiation treatment, although initiation rates were quite low, i.e. in the range $2.4-25.3 \%$. Our results confirmed previous observations that secondary EMs can be induced following careful examination of explants to avoid false-positive lines (i.e. regrowth of residual embryonal cells attached to cotyledonary SEs, Klimaszewska et al. 2009). Interest in secondary somatic embryogenesis is about enhancing the embryogenic potential of the embryogenic cultures, as demonstrated in hybrid larch and maritime pine (Lelu et al. 1994; Klimaszewska et al. 2009). It is also a way to restore the embryogenic potential of lines affected by ageing effects after subculturing for several months, as observed in some conifer species such as pine. This can be particularly useful if the line is not cryopreserved or if the cryopreserved stock must be carefully managed (Klimaszewska et al. 2009). In Douglas-fir we did not detect any ageing effect after continuous culture of lines for 5 years. Therefore, possible practical applications of secondary somatic embryogenesis in this species relate to enhancing embryogenic potential. Secondary lines displayed significantly higher embryogenic potential when the original lines exhibited poor maturation ability, i.e. SD4 (mean of 1343 vs 478 SEs $^{-1}$ f.m.), and TD17 (148 vs 30 SEs $\mathrm{g}^{-1}$ f.m.). In contrast, no improvement could be obtained for already highly productive lines (TD1, TD15) with both primary and secondary lines producing over 1000 cotyledonary SEs g${ }^{1}$ f.m. In maritime pine, Klimaszewska et al. (2009) described a similar variable effect of secondary somatic embryogenesis on embryogenic potential of original lines compared with primary lines.

Improved embryogenic potential of the less productive genotypes after a second cycle of somatic embryogenesis initiation may result from differential expression of embryogenesisrelated genes through epigenetic mechanisms. Genetic mechanisms (accumulation of mutations in embryogenesis-related genes) during somatic embryogenesis cannot be excluded (reviewed in Miguel et al. 2016), but these are unlikely to affect multiple embryogenesis-related genes simultaneously.

The question of SEs quality has changed little over the years. It is generally accepted that good quality SEs correspond to embryos with a very high germination rate, producing vigorous somatic seedlings. Thus, SE quality is often assessed by the yield of normal-shaped SEs produced and their ability to germinate. However, depending on the species, the ability to germinate does not necessarily indicate the future vigour of the somatic seedlings, as shown by the germination frequencies in this study of Douglas fir. It was very close to $100 \%$, whatever the maturation stage of the SEs (Table 3). However, numerous studies have shown that an analysis of the content, and more precisely of the storage reserves, allows prediction of the final behaviour of the germinated embryos and their vigour, since these parameters are correlated. This is why seed producers often consider the weight of 1000 seeds (International Seed Testing Association recommendation). Recently, Noa et al. (2013) also stated that maturation is a critical feature for evaluating the potential quality and viability of somatic seedlings. Thus, in this study we measured the protein content in SEs during maturation. It increased during the last weeks of maturation, reaching a maximum at 7 weeks. Beyond this time, the content was stable or decreased. This phenomenon was more marked in green embryos that had already started germinating, as previously reported in Scots pine (Lelu-Walter et al. 2008). This process leads to a degradation of the storage proteins as confirmed by the corresponding protein profile (Fig. 8). Based on these two results, we could conclude that the Douglas-fir SEs completed their maturation after 7 weeks. Even if the SEs, after 5 or 6 weeks of maturation, appeared 
Version définitive du manuscrit publié dans / Final version of the manuscript published in : Plant Cell, Tissue and Organ Culture, 2018, 132(1) 137-155

morphologically similar, their intrinsic quality was lower on the basis of their protein content. Nevertheless, at the end of the maturation process, the 7-week SEs of Douglas-fir had a much lower protein content than that in mature ZEs or megagametophyte of dry seeds. This difference observed between both types of embryos differed from previous reports for Scots pine (LeluWalter et al. 2008), and hybrid larch (Teyssier et al. 2014; von Aderkas et al. 2015). AberlencBertossi explained such a difference on the basis of a lower accumulation of storage transcripts in SEs and protease activity, for storage mobilization, present throughout somatic embryogenesis but absent in the zygotic counterpart (Aberlenc-Bertossi et al. 2008). More basically, the difference would have been reduced if the comparison had been made with ZEs from fresh seeds (Morel et al. 2014b). The electrophoretic comparison of the proteins present in 7-week SEs and mature ZEs confirmed their equivalent quality, with major storage proteins present. We identified them and confirmed their hypothetical identities in the ZEs and megagametophyte in Douglas-fir (Green et al. 1991) as vilicin-like protein and legumin-like protein (Fig. 8).

Seeds can exhibit high levels of germination followed by low seedling vigour. We observed this in our study, with a significant difference in the total number of plantlets according to the duration of maturation $(\mathrm{P}<0.0004)$, whilst the level of germination exhibited no difference. More surprisingly the SEs that had accumulated more storage proteins (7 weeks maturation) produced fewer plantlets than SEs matured for 5 weeks (Table 4). The maturation process consists of a phase of cell development leading to the production of cotyledonary embryos and a strict maturation phase during which the cotyledonary SEs accumulate energy reserves (see the increase in the protein content between 5 and 7 weeks) and acquire tolerance to desiccation. In the seed, the embryo then enters dormancy, and germination cannot take place before the dormancy is broken by stratification. We can then assume that the increase in protein content is counteracted by onset of dormancy. When storage reserves were high (7-week SEs), germination followed by plantlet conversion was less affected by SEs desiccation (Table 3). Another factor to consider is the progressive and sequential mobilization of the storage proteins during germination according to the nature of the storage protein (Forward et al. 2001), first the vicilin-like protein and then the legumin-like protein, the latter being more abundant. It is, therefore, to be expected that the total protein content has a greater influence on the number of plantlets obtained than the number of germinated SEs.

According to Terskikh et al. (2005) "Seedling vigour and the potential for early growth following germination is ultimately dependent upon processes that occurred earlier (during conifer seed development)...". In crops where seedling vigour is crucial, monitoring of the SEs maturation by storage protein deposition has been reported (Sterk and de Vries 1993). Therefore, in the field of conifer reproduction, any development of maturation protocol should be accompanied by a physiological analysis of SEs.

Current experiments are being conducted to examine improvement in the quality of plantlets prior to transfer to the ex-vitro environment in order to increase the likelihood of successful acclimatization.

\section{Conclusions}

In this work, somatic embryogenesis protocol for Douglas-fir was refined, resulting in enhanced embryogenic potential at the maturation step. Key factors include: high gellan gum content, low cell density per filter paper disc on the maturation medium and also initiation of secondary embryogenic lines. We demonstrated, for the first time in this species, that secondary somatic embryogenesis can be induced from mature, cotyledonary SEs. Interestingly, secondary EM cultures were able to produce a significantly higher number of cotyledonary SEs compared with the original, primary EM cultures. This effect was highlighted in the specific case of the less productive genotypes (TD17, SD4 in this study) and must now be confirmed for a wider range 
Version définitive du manuscrit publié dans / Final version of the manuscript published in : Plant Cell, Tissue and Organ Culture, 2018, 132(1) 137-155

of embryogenic lines. Significant practical implications are expected as a result of the work in our laboratories in France and New Zealand, since low embryogenic potential is one of factors affecting breeding (field archives, clonal tests) and deployment of improved varieties (varietal testing, production up-scaling) through somatic embryogenesis in Douglas-fir and other conifers (Lelu-Walter et al. 2013, 2016).

Based on the above and previously published data (Reeves et al. in press), an efficient method for production of large quantities of plants from a number of genotypes was developed and is available in the public domain. We recommend the following:

- $\quad$ Culturing of immature zygotic embryos on Glitz induction medium supplemented with $2.3 \mu \mathrm{M}$ 2,4-D, $2.2 \mu \mathrm{M}$ BA, $0.087 \mathrm{M}$ sucrose and solidified with $3 \mathrm{~g} \mathrm{~L}^{-1}$ of gellan gum $\left(\right.$ Phytage $\mathrm{l}^{\circledR}$ ), without subculturing during the whole initiation period.

- $\quad$ Proliferation of the EMs on a filter paper disc to obtain a rapid increase in tissue fresh mass, using Glitz medium supplemented with $4.5 \mu \mathrm{M}$ 2,4-D, $2.2 \mu \mathrm{M}$ BA, $0.087 \mathrm{M}$ maltose and solidified with $4 \mathrm{~g} \mathrm{~L}^{-1}$ of gellan gum.

- Maturation in darkness on a filter paper disc for 8 weeks on Glitz basal medium supplemented with $0.2 \mathrm{M}$ sucrose, $60 \mu \mathrm{M}$ ABA and $10 \mathrm{~g} \mathrm{~L}^{-1}$ gellan gum. No subculturing is necessary during the entire maturation period. Cell density on the filter may be adjusted in the range 50-100 $\mathrm{mg}$ per filter.

- $\quad$ For poorly-productive embryogenic lines, we recommend initiating secondary somatic embryogenesis. Cotyledonary SEs 5-6 weeks old are transferred to induction medium i.e. Glitz supplemented with $4.5 \mu \mathrm{M} 2,4-\mathrm{D}, 4.4 \mu \mathrm{M}$ BA, $0.087 \mathrm{M}$ sucrose and solidified with $4 \mathrm{~g} \mathrm{~L}^{-1}$ of gellan gum.

- $\quad$ Mature cotyledonary SEs are harvested after 7 weeks of maturation, the best period to achieve the desired results.

- Germination of cotyledonary SEs on plant growth regulator-free Glitz medium, in darkness for an initial 7 days, followed by exposure to dim light.

- Transfer of plants from the Petri dishes to ex-vitro conditions during the vigorous growth phase, and acclimatization under shade house conditions (initially with high relative humidity). We were able to acclimatize a number of plants, however, further optimization of this step is required.

\section{Acknowledgements}

This research was partially funded by Future Forests Research Limited and a grant from the French Ministry of Foreign Affairs and the French Ministry of Higher Education and Research, and Technology Support Programme and Core funding provided by The Ministry of Business, Innovation and Employment in New Zealand through the France / New Zealand Science Cooperation Programme Dumont d'Urville ( $\left.{ }^{\circ} 25815 \mathrm{PH}\right)$. We would like to acknowledge the support of the University of Limoges, and The Chair of Excellence Forest Resources and Wood Uses, for the grant to Florian Gautier.

\section{Author contribution statement}

MALW designed and coordinated the study, carried out somatic embryogenesis and drafted the manuscript. FG participated in somatic embryogenesis and helped to draft the manuscript. KE performed histological and microscopic analyses and drafted the manuscript. LS performed the statistical analyses and drafted the manuscript. CT performed protein analysis and drafted the manuscript. AML carried out mass spectrometric analysis and helped to draft the manuscript. CLM carried out somatic embryogenesis and collected the material. $\mathrm{CH}$ participated in the design of the study and helped to draft the manuscript. JFT participated in the design of the study and drafted the manuscript. CR performed English editing and drafted the manuscript. All authors read and approved the final manuscript. 


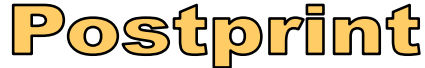

Version définitive du manuscrit publié dans / Final version of the manuscript published in :

Plant Cell, Tissue and Organ Culture, 2018, 132(1) 137-155

http://dx.doi.org/10.1007/s11240-017-1318-0

\section{Compliance with ethical standards}

Conflict of interest The authors declare that they have no conflict of interest.

\section{References}

Aberlenc-Bertossi F, Chabrillange N, Duval Y, Tregear J (2008) Contrasting globulin and cysteine proteinase gene expression patterns reveal fundamental developmental differences between zygotic and somatic embryos of oil palm. Tree Physiol 28: 1157-1167

Abrahamsson M, Valladares S, Larsson E, Clapham D, von Arnold S (2012) Patterning during somatic embryogenesis in Scots pine in relation to polar auxin transport and programmed cell death. Plant Cell Tissue Organ Culture 109: 391-400

Abrahamsson M, Valladares S, Merino I, Larsson E, von Arnold S (2017) Degeneration pattern in somatic embryos of Pinus sylvestris L. In Vitro Cell Dev Biol-Plant 53: 88-96

Beneš K, Kamínek M (1973) The use of aluminium lake of nuclear fast red in plant material successively with alcian blue. Biologia Plantarum 15: 294-297

Bonga JM (2015) A comparative evaluation of the application of somatic embryogenesis, rooting of cuttings, and organogenesis of conifers. Can J For Res 45: 1-5

Cvikrová M, Z. V, Eliášová K, Pešek B, Trávníčková A, Vágner M (2016) The impact of UV$B$ irradiation applied at different phases of somatic embryo development in Norway spruce on polyamine metabolism. Trees 30: 113-124

Dean CA, Welty DE, Herold GE (2009) Performance and Genetic Parameters of Somatic and Zygotic Progenies of Coastal Douglas-fir at 71/2-Years across Washington and Oregon, USA. Silvae Genetica 58: 212-219

Dungey HS, Low CB, Lee J, Miller MA, Fleet K, Yanchuk AD (2012) Developing breeding and deployment options for Douglas-fir in New Zealand: breeding for future forest conditions. Silvae Genetica 61: 104-115

Durzan DJ, Gupta PK (1987) Somatic embryogenesis and polyembryogenesis in Douglas-fir cell suspension cultures. Plant Sci 52: 229-235

Eastman PAK, Webster FB, Pitel JA, Roberts DR (1991) Evaluation of somaclonal variation during somatic embryogenesis of interior spruce (Picea glauca engelmannii complex) using culture morphology and isozyme analysis. Plant Cell Reports 10: 425-430

Forward BS, Tranbarger TJ, Misra S (2001) Characterization of proteinase activity in stratified Douglas-fir seeds. Tree Physiol 21: 625-629

Green MJ, Mc Leod JK Misra S (1991) Characterization of Douglas fir protein body composition by SDS-PAGE and electron microscopy. Plant Physiol Bioch 29: 49-55

Gupta PK (1996) Method for reproducing conifers by somatic embryogenesis using a maltose enriched maintenance medium: US Patent No. 5,563,061. Washington, DC: U.S. Patent and Trademark Office

Gupta PK, Pullman GS (1996) Method for reproducing Douglas-fir by somatic embryogenesis. U.S. Patent No. 5,482,857. Washington, DC: U.S. Patent and Trademark Office

Gupta PK, Timmis R (2005) Mass propagation of conifer trees in liquid cultures-progress towards commercialization. Plant Cell Tissue Organ Culture 81: 339-346

Gupta PK, Timmis R, Timmis KA, Carlson WC, Welty EDE (1995) Somatic embryogenesis in Douglas-fir (Pseudotsuga menziesii). In: Jain S, Gupta P, Newton R (eds) Somatic embryogenesis in woody plants, Vol. 3 Kluwer Academic Publishers, Dordrecht, The Netherlands, pp. 303-313

Hakman I, Hallberg H, Palovaara J (2009) The polar auxin transport inhibitor NPA impairs embryo morphology and increases the expression of an auxin efflux facilitator protein PIN during Picea abies somatic embryo development. Tree Physiol 29: 483-496 
Version définitive du manuscrit publié dans / Final version of the manuscript published in :

Plant Cell, Tissue and Organ Culture, 2018, 132(1) 137-155

http://dx.doi.org/10.1007/s11240-017-1318-0

Hargreaves CL, Reeves CB, Find JI, Gough K, Josekutty P, Skudder DB, Van der Maas SA, Sigley MR, Menzies MI, Low CB, Mullin TJ (2009) Improving initiation, genotype capture, and family representation in somatic embryogenesis of Pinus radiata by a combination of zygotic embryo maturity, media, and explant preparation. Can J For Res 39: 1566-1574

Hargreaves CL, Reeves CB, Find JI, Gough K, Menzies MI, Low CB, Mullin TJ (2011) Overcoming the challenges of family and genotype representation and early cell line proliferation in somatic embryogenesis from control-pollinated seeds of Pinus radiata. New Zealand J For Sci 41: 97-114

Harvengt L, Trontin JF, Reymond I, Canlet F, Pâques M (2001) Molecular evidence of true-totype propagation of a 3-year-old Norway spruce through somatic embryogenesis. Planta 213: 828-832

Hermann RK, Lavender DP (1999) Douglas-fir planted forests. New Forests 17:53-70

Hong L, Boulay M, Gupta PK, Durzan DJ (1992) Variations in somatic polyembryogenesis: induction of adventitious embryonal-suspensor masses on developing Douglas-fir embryos. In: Ahuja. MR (ed) Woody Plant Biotechnology, Vol. 210 New York: Plenum Press, pp.105121

Isah T (2016) Induction of somatic embryogenesis in woody plants. Acta Physiol. Plant. 38: 118-139

Käll L, Canterbury JD, Weston J, Noble WS, MacCoss MJ (2007) Semi-supervised learning for peptide identification from shotgun proteomics datasets. Nat Methods 4: 923-925

Klimaszewska K, Smith D (1997) Maturation of somatic embryos of Pinus strobus is promoted by a high concentration of gellan gum. Physiol Plant 100: 949-957

Klimaszewska K, Bernier-Cardou M, Cyr DR, Sutton BCS (2000) Influence of gelling agents on culture medium gel strength, water availability, tissue water potential, and maturation response in embryogenic cultures of Pinus strobus L. In Vitro Cell Dev Biol-Plant 36: 279286

Klimaszewska K, Noceda C, Pelletier G, Label P, Rodriguez R, Lelu-Walter M-A (2009) Biological characterization of young and aged embryogenic cultures of Pinus pinaster (Ait.). In Vitro Cell Dev Biol-Plant 45: 20-33

Klimaszewska K, Overton C, Stewart D, Rutledge RG (2010) Initiation of somatic embryos and regeneration of plants from primordial shoots of 10-year-old somatic white spruce and expression profile of 11 genes followed during tissue culture process. Planta 233: 635-647

Klimaszewska K, Hargreaves CL, Lelu-Walter M-A, Trontin J-F (2016) Advances in conifer somatic embryogenesis since year 2000. In: Germanà MA, Lambardi M (eds) In vitro embryogenesis in Higher plants, Chap. 7, Methods in Molecular Biology, Springer Science + Business Media, New York, pp.131-162, doi:10.1007/978-1-4939-3061-6_8

Kong L, von Aderkas P (2011) A novel method of cryopreservation without a cryoprotectant for immature somatic embryos of conifer. Plant Cell Tissue Organ Culture 106:115-125

Kong L, Denchev P, Radley R, Lobatcheva II, Attree SM (2012) Method of culturing conifer somatic embryos using S (+)- abscisic acid. U.S. Patent No. US 8,124,412 B2. Washington, DC: U.S. Patent and Trademark Office

Lelu M-A, Klimaszewska K, Charest P (1994) Somatic embryogenesis from immature and mature zygotic embryos and from cotyledons and needles of somatic plantlets of Larix. Can $\mathrm{J}$ For Res 24:100-106

Lelu M-A, Bastien C, Drugeault A, Gouez ML, Klimaszewska K (1999) Somatic embryogenesis and plantet development in Pinus sylvestris and Pinus pinaster on medium with and without growth regulators. Physiol Plant 105: 719-728

Lelu-Walter M-A, Pâques LE (2009) Simplified and improved somatic embryogenesis of hybrid larches (Larix x eurolepis and Larix x marschlinsii). Perspectives for breeding. Ann For Sci 66: 104 
Version définitive du manuscrit publié dans / Final version of the manuscript published in :

Plant Cell, Tissue and Organ Culture, 2018, 132(1) 137-155

Lelu-Walter M-A, Bernier-Cardou M, Klimaszewska K (2008) Clonal plant production from self- and cross-pollinated seed families of Pinus sylvestris (L.) through somatic embryogenesis. Plant Cell Tissue Organ Culture 92: 31-45

Lelu-Walter M-A, Thompson D, Harvengt L, Sanchez L, Toribio M, Pâques LE (2013) Somatic embryogenesis in forestry with a focus on Europe: state-of-the-art, benefits, challenges and future direction. Tree Gene Genomes 9: 883-899

Lelu-Walter M-A, Klimaszewska K, Miguel C, Aronen T, Hargreaves C, Teyssier C, Trontin J-F (2016) Somatic embryogenesis for more effective breeding and deployment of improved varieties in Pinus spp.: bottlenecks and recent advances. In: Loyola-Vargas VM, Ochoa-Alejo N (eds) Somatic Embryogenesis - Fundamental Aspects and Applications. Chap 19, Springer Verlag, pp319-365. DOI: 10.1007/978-3-319-33705-0_19

Litvay JD, Verma DC, Johnson MA (1985) Influence of a loblolly pine (Pinus taeda L.). Culture medium and its components on growth and somatic embryogenesis of the wild carrot (Daucus carota L.). Plant Cell Reports 4: 325-328

Merkle S, Cunningham M (2011) Southern hardwood varietal forestry: a new approach to shortrotation woody crops for biomass energy. J For 109: 7-14

Miguel CM, Rupps A, Raschke J, Rodrigues AS, Trontin J-F (2016) Impact of molecular studies on somatic embryogenesis development for implementation in conifer multi-varietal forestry. In: Park Y-S, Bonga JM, Moon H-K (eds) Vegetative Propagation of Forest trees Korea Forest Research Institute, Seoul, Korea, pp. 373-421. ISBN 978-89-8176-064-9

Ministry of Agriculture and Forestry (2011) A national exotic forest description as at April 152010. $\quad$ Retrieved 27 November 2011, from http://www.maf.govt.nz/newsresources/publications

Miller JT, Knowles FB (1994) Introduced forest trees in New Zealand: Recognition, role and seed source. Forest Research Bulletin No. 124. No. 14. Douglas-fir Pseudotsuga menziesii (Mirbel) Franco. 37p.

Morel A, Teyssier C, Trontin JF, Eliášová K, Pešek B, Beaufour, Morabito D, Boizot N, Le Metté C, Belal-Bessai L, Reymond I, Harvengt L, Cadene M, Corbineau F, Vágner M, Label P, Lelu-Walter MA (2014a) Early molecular events involved in Pinus pinaster Ait. somatic embryo development under reduced water availability: transcriptomic and proteomic analyses. Physiol Plant 152: 184-201

Morel A, Trontin JF, Corbineau F, Lomenech A-M, Beaufour M, Reymond I, Le Metté C, Ader K, Harvengt L, Cadene M, Label P, Teyssier C, Lelu-Walter M-A (2014b) Cotyledonary somatic embryos of Pinus pinaster Ait. most closely resemble fresh, maturing cotyledonary zygotic embryos: biological, carbohydrate and proteomic analyses. Planta 240: 1075-1095

Muñoz F, Sanchez L (2015) breedR: Statistical Methods for Forest Genetic Resources Analysts. R package version 0.11. https://github.com/famuvie/breedR.

Noah AM, Niemenak N, Sunderhaus S, Haase C, Omokolo DN, Winkelmann T, Braun H-P (2013) Comparative proteomic analysis of early somatic and zygotic embryogenesis in Theobroma cacao L. Journal of Proteomics 78: 123-133

Pullman GS, Zhang Y, Phan BH (2003) Brassinolide improves embryogenic tissue initiation in conifers and rice. Plant Cell Reports 22: 96-104

Pullman, GS, Mein J, Johnson S, Zhang Y (2005) Gibberellin inhibitors improve embryogenic tissue initiation in conifers. Plant Cell Reports 23: 596-605

$\mathrm{R}$ Core Team (2016) R: A language and environment for statistical computing. R Foundation for Statistical Computing, Vienna, Austria. URL https://www.R-project.org/.

Reeves C, Hargreaves C, Trontin J-F, Lelu-Walter M-A (2017) Simple and efficient protocols for the initiation and proliferation of embryogenic tissue of Douglas-fir. Trees (in press)

Ruaud JN (1993) Maturation and conversion into plantlets of somatic embryos derived from needles and cotyledons of 7, 56-day-old Picea abies. Plant Sci 92: 213-220

Ruaud JN, Bercetche J, Pâques M (1992) First evidence of somatic embryogenesis from needles of 1-year-old Picea abies plants. Plant Cell Reports 11: 563-566 
Version définitive du manuscrit publié dans / Final version of the manuscript published in :

Plant Cell, Tissue and Organ Culture, 2018, 132(1) 137-155

Saly S, Joseph C, Corbineau F, Lelu M-A, Côme D (2002) Induction of secondary somatic embryogenesis in hybrid larch (Larix x leptoeuropaea) as related to ethylene. Plant Growth Regul 37: 287-294

Shelbourne, CJA, Low CB, Gea LD, Knowles RL (2007) Achievements in forest tree genetic improvement in Australia and New Zealand 5: Genetic improvement of Douglas-fir in New Zealand. Australian Forestry 70: 28-32

Sterk P, de Vries S (1993) Molecular markers for plant embryos. In: Redenbaugh K (ed) Synseeds: Applications of synthetic seeds to crop improvement (pp. 115-132). CRC Press, Boca Raton

Taber, RP, Zhang C, Hu WS (1998) Kinetics of Douglas-fir (Pseudotsuga menziesii) somatic embryo development. Can J Bot 76: 863-871

Terskikh VV, Feurtado JA, Borchardt S, Giblin M, Abrams SR, Kermode AR (2005) In vivo ${ }^{13} \mathrm{C}$ NMR metabolite profiling: potential for understanding and assessing conifer seed quality. J Exp Bot 56: 2253-2265

Teyssier C, Grondin C, Bonhomme L, Lomenech A-M, Vallance M, Morabito D, Label P, LeluWalter MA (2011) Increased gelling agent concentration promotes somatic embryo maturation in hybrid larch (Larix x eurolepis): a 2- DE proteomic analysis. Physiol Plant 141: $152-165$

Teyssier C, Maury S, Beaufour M, Grondin C, Delaunay A, Le Metté C, Ader K, Cadene M, Label P, Lelu-Walter MA (2014) In search of markers for somatic embryo maturation in hybrid larch (Larix x eurolepis): global DNA methylation and proteomic analyses. Physiol Plant 150: 271-291

Timmis R, Grob JA, Gupta PK, Rayfield SD (2011) Methods for increasing germination vigor by early singulation of conifer somatic embryos. U.S. Patent No. 7,964,404. Washington, DC: U.S. Patent and Trademark Office

Trontin J-F, Klimaszewska K, Morel A, Hargreaves C, Lelu-Walter M-A (2016a). Molecular aspects of conifer zygotic and somatic embryo development: a review of genome-wide approaches and recent insights. In: Germanà MA, Lambardi M (eds) In Vitro Embryogenesis in Higher Plants, Methods in Molecular Biology, vol. 1359, Chapter 8, Springer Science+Business Media New York, pp. 167-207. DOI 10.1007/978-1-4939-3061-6_8

Trontin J-F, Aronen T, Hargreaves C, Montalbán IA, Moncaleán P, Reeves C, Quoniou S, LeluWalter M-A, Klimaszewska K (2016b) International effort to induce somatic embryogenesis in adult pine trees. In: Park Y-S, Bonga JM, Moon H-K (eds) Vegetative Propagation of Forest Trees. Korea Forest Research Institute Seoul, Korea, pp. 211-260. ISBN 978-89-8176-064-9 Uddenberg D, Valladares S, Abrahamsson M, Sundström JF, Sundås-Larsson A, von Arnold S (2011) Embryogenic potential and expression of embryogenesis-related genes in conifers are affected by treatment with a histone deacetylase inhibitor. Planta 234: 527-539

von Aderkas P, Bonga JM (2000) Influencing micropropagation and somatic embryogenesis in mature trees by manipulation of phase change, stress and culture environment. Tree Physiol 20: 921-928

von Aderkas Patrick, Teyssier C, Charpentier JP, Gutmann M, Pâques L, Le Metté C, Ader K, Label P, Kong L, Lelu-Walter M-A (2015) Effect of light conditions on anatomical and biochemical aspects of somatic and zygotic embryos of hybrid larch (Larix x marschlinsii). Annals of Botany 115: 605-615

Vondráková Z, Cvikrová M, Eliášová K, Martincová O, Vágner M (2010) Cryotolerance in Norway spruce and its association with growth rates, anatomical features and polyamines of embryogenic cultures. Tree Physiol 30: 1335-1348

Vondráková Z, Eliášová K, Fischerová L, Vágner M (2011) The role of auxins in somatic embryogenesis of Abies alba. Central European Journal of Biology 6: 587-596

Vondráková Z, Eliášová K, Vágner M, Martincová O, Cvikrová M (2015) Exogenous putrescine affects endogenous polyamine levels and the development of Picea abies somatic embryos. Plant Growth Regul 75: 405-414 


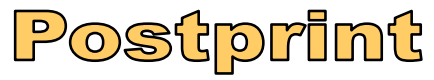

Version définitive du manuscrit publié dans / Final version of the manuscript published in :

Plant Cell, Tissue and Organ Culture, 2018, 132(1) 137-155 http://dx.doi.org/10.1007/s11240-017-1318-0

983

984

985

986

987

988

989

990

991

992

993

994

995

996

997

998

999

1000

1001

\% 1002

1003

1004

1005

1006

1007

1008

1009

1010

1011

1012

1013

1014

1015

1016

1017

1018

1019

1020

1021

1022

1023

1024

1025

1026

1027

1028

1029

1030

1031

1032

1033

1034

Vooková B, Kormuták A (2006) Comparison of induction frequency, maturation capacity and germination of Abies numidica during secondary somatic embryogenesis. Biologia Plantarum 50: $785-788$

\section{Figure legends}

Fig. 1 Genetic origin of the Douglas-fir plant material analysed in this work (primary and secondary embryogenic lines). Embryonal masse (EM) initiation during secondary somatic embryogenesis is shown at the base of the hypocotyl region, above the embryonal root cap (red star).

Fig. 2 Cytological aspects of the proliferating Douglas-fir embryonal mass.

a- Extensive polyembryogenic centre with meristematic cells $(\mathrm{m})$ joined to intact suspensor cells (s); Space among loosely arranged suspensor cells located below intact suspensor cells is filled with mucilaginous extracellular matrix (star); arrowheads point to disintegrated dead mass anchoring the polyembryogenic centre within the embryonal mass.

b - Individual embryo with embryonal head (eh) joined to compact long suspensor (s); suspensor cells are linked up with mucilaginous extracellular matrix (star).

c - Smaller polyembryogenic centre with loosely arranged suspensor cells (s). Note the mucilaginous extracellular matrix among these cells (star).

$\mathrm{d}, \mathrm{e}$-Two successive sections of a polyembryogenic centre showing meristematic cells $(\mathrm{m})$ and tightly joined outer suspensor cells (d) and loosely arranged suspensor cells inside the cell "package" of the polyembryogenic centre (e).

Paraffin sections stained with Alcian Blue/ Nuclear Fast Red; Scale bars: $a=500 \mu \mathrm{m} ; \mathrm{b}, \mathrm{c}, \mathrm{d}$,e $=200 \mu \mathrm{m}$

m - meristem, s- suspensor cells, arrowheads - dead cellular mass, star (asterisks) mucilaginous extracellular matrix

Fig. 3 Viability of cells in proliferating Douglas-fir early somatic embryos.

Large (a) and smaller (b) polyembryogenic centres with highly viable meristematic cells and less viable suspensor cells growing out of the dead cell mass (note the red spots indicating nuclei of dead cells).

(c) Individual, somatic embryo with highly viable meristematic cells and a mosaic of viable and dead cells within the suspensor.

(d) Small embryos with highly viable meristematic and suspensor cells growing near or out of the dead mass.

Green: fluorescence of fluorescein produced from FDA in viable cells.

Red: fluorescence of PI-DNA complexes in non-viable or dead cells

Scale bars $=100 \mu \mathrm{m}$

Fig. 4 Somatic embryo of Douglas-fir after maturation for 8 weeks.

(a) Cotyledonary somatic embryos of high-quality morphological standard.

(b) Abnormally developed somatic embryos with a shooty aspect. Note the poorly developed and/or inflated hypocotyl as well as poorly elongated and cotyledons turning a greenish colour. Scale bars: $3 \mathrm{~mm}(\mathrm{a}), 2 \mathrm{~mm}$ (b)

Fig. 5 Effects of gellan gum concentration $\left(8\right.$ and $\left.10 \mathrm{~g} \mathrm{~L}^{-1}\right)$ and cell density on the filter paper (50 and $100 \mathrm{mg}$ f.m. per filter) during maturation of somatic embryos for seven embryogenic lines of Douglas-fir (TD1, TD2, TD6, TD13, TD15, TD17 and SD4). (a) Number of cotyledonary SEs g ${ }^{-1}$ f.m. (= embryogenic potential); (b) Number of shooty SEs g ${ }^{-1}$ f.m. 


\section{Supporting information}

Supplementary data 1: Mucilaginous extracellular matrix located between suspensor cells of an early somatic embryo of Douglas-fir (stars); Scale bar $=50 \mu \mathrm{m}$; paraffin section stained with Alcian Blue and Nuclear Fast Red.

Supplementary data 2. Preliminary maturation $\mathrm{N}^{\circ} 1$ : effects of gellan gum concentration (6 and $\left.8 \mathrm{~g} \mathrm{~L}^{-1}\right)$, and embryonal masses density on the filter paper disc $(50,100$ and $200 \mathrm{mg}$ f.m. per filter) during maturation on development of somatic embryos for 5 embryogenic lines of Douglas-fir (TD1, TD2, TD6, TD15, TD17 and SD4). A: Number of cotyledonary SEs $\mathrm{g}^{-1}$ f.m. (= embryogenic potential); B: Number of shooty SEs $\mathrm{g}^{-1}$ f.m.

Supplementary data 3 . Preliminary maturation $N^{\circ} 2$ : effects of gellan gum concentration $(6,8$ and $\left.10 \mathrm{~g} \mathrm{~L}^{-1}\right)$, embryonal masses density on the filter paper disc (50 and $100 \mathrm{mg}$ f.m. per filter) and abscisic acid (ABA) concentration $(60$ and $80 \mu \mathrm{M})$ on development of somatic embryos for 2 embryogenic lines of Douglas-fir (TD1 $\square$ and TD15 ). A: Number of cotyledonary SEs $\mathrm{g}^{-1}$ f.m. (= embryogenic potential); B: Number of shooty SEs $\mathrm{g}^{-1}$ f.m.

Supplementary data 4. Germination and plantlet frequencies of cotyledonary somatic embryos (SEs) of Douglas fir in the presence/absence of activated charcoal (AC) in the germination medium. 
Version définitive du manuscrit publié dans / Final version of the manuscript published in :

Plant Cell, Tissue and Organ Culture, 2018, 132(1) 137-155 http://dx.doi.org/10.1007/s11240-017-1318-0

TD17 4.5 9

SD4

$$
4.5
$$

9 0.11 .

http://dx.doi.org/10.1007/s11240-017-13 embryos (SEs) of Douglas-fir according to 2.4-D concentration and embryogenic line.

\begin{tabular}{ccccc}
\hline Line & $\begin{array}{c}2,4-\mathrm{D} \text { concentration } \\
(\mu \mathrm{M})\end{array}$ & $\begin{array}{l}\text { No of SEs } \\
\text { cultured }\end{array}$ & \multicolumn{2}{c}{ No SEs with EMs } \\
\cline { 3 - 5 } & & 80 & Total & $\%$ \\
\hline TD1 & 4.5 & 160 & 10 & 12.5 \\
& 9 & 70 & 2 & 2.8 \\
TD15 & 4.5 & 110 & 6 & 5.4 \\
& 9 & 60 & 7 & 11.6 \\
TD17 & 4.5 & 30 & 0 & \\
& 9 & 100 & 31 & 31.0 \\
& & & & \\
SD4 & 4.5 & 70 & 12 & 17.1 \\
& 9 &
\end{tabular}

Differences between genotypes: $\chi^{2}=39.69, p=5 \times 10^{-4}$; differences between 2,4-D concentration: $\chi^{2}=8.86, p=$

Table 2 Mean yield of cotyledonary somatic embryos (SEs) developed after 8 weeks of maturation from primary (TD1, TD15, TD17, SD4) and secondary (TD1-2, TD15-1, TD15-2, TD17-3, SD4-1, SD4-4, SD4-7) embryogenic lines of Douglas-fir.

\begin{tabular}{lrrr}
\hline Line & $\begin{array}{l}\text { No of SEs }\left(\mathrm{g}^{-1}\right. \\
( \pm 95 \% \text { f.m. })\end{array}$ & \\
\hline Primary & & & \\
TD1 & 1744 & \pm & 323 \\
TD15 & 1659 & \pm & 339 \\
TD17 & 30 & \pm & 19 \\
SD4 & 478 & \pm & 139 \\
& & & \\
Secondary & & & \\
TD1-2 & 2069 & \pm & 346 \\
TD15-1 & 1117 & \pm & 282 \\
TD15-2 & 931 & \pm & 312 \\
TD17-3 & 148 & \pm & 92 \\
SD4-1 & 1065 & \pm & 242 \\
SD4-4 & 1646 & \pm & 292 \\
SD4-7 & 1319 & \pm & 185 \\
\hline
\end{tabular}

Significance of observed differences between primary and secondary lines is illustrated in Fig. 6 
Version définitive du manuscrit publié dans / Final version of the manuscript published in : Plant Cell, Tissue and Organ Culture, 2018, 132(1) 137-155 http://dx.doi.org/10.1007/s11240-017-1318-0

Table 3 Germination and plantlet frequencies of cotyledonary somatic embryos (SEs) of Douglas fir according to maturation duration.

\begin{tabular}{|c|c|c|c|c|c|}
\hline \multirow[t]{2}{*}{ Genotype } & \multirow{2}{*}{$\begin{array}{l}\text { Maturation } \\
\text { (week) }\end{array}$} & \multicolumn{2}{|c|}{ No SEs germinated } & \multicolumn{2}{|c|}{ No of Plant * } \\
\hline & & Total & $\%$ & Total & $\%$ \\
\hline \multirow[t]{3}{*}{ TD1 } & 5 & 60 & 100 & 59 & 98 \\
\hline & 6 & 58 & 97 & 44 & 76 \\
\hline & 7 & 59 & 98 & 53 & 89 \\
\hline \multirow[t]{4}{*}{ TD13 } & 5 & 59 & 98 & 55 & 93 \\
\hline & 6 & 60 & 100 & 44 & 73 \\
\hline & 7 & 60 & 100 & 32 & 53 \\
\hline & 8 & 58 & 97 & 40 & 69 \\
\hline \multirow[t]{4}{*}{ TD15 } & 5 & 59 & 98 & 54 & 91 \\
\hline & 6 & 60 & 100 & 42 & 70 \\
\hline & 7 & 60 & 100 & 44 & 73 \\
\hline & 8 & 59 & 98 & 50 & 85 \\
\hline
\end{tabular}

Test of differences between genotypes at the germination stage: $\chi^{2}=0.041, p=0.98$ (nonsignificant); at the plantlet stage: $\chi^{2}=16.571, p=0.28$ (non-significant). Test of differences between maturation duration classes at the germination stage: $\chi^{2}=2.795, p=0.593$ (non-significant); at the plantlet stage: $\chi^{2}=59.83, p=0.0004$ (significant).

* Germination rate was estimated after 4 weeks and conversion rate after 10 weeks on germination medium. SEs were considered germinated as soon as radicle elongation occurred. Germinated SEs were considered to have become plantlets as soon as epicotyl development was observed. 
Version définitive du manuscrit publié dans / Final version of the manuscript published in :

Plant Cell, Tissue and Organ Culture, 2018, 132(1) 137-155 http://dx.doi.org/10.1007/s11240-017-1318-0

Table 4 Total protein content in cotyledonary somatic embryos (SEs) from two Douglas-fir embryogenic lines (TD1, TD15) according to maturation duration and with reference to protein content in zygotic embryos (ZEs) and megagametophytes from mature dry seeds (same full-sib family as SEs).

\begin{tabular}{|c|c|c|}
\hline Embryo & $\begin{array}{l}\text { Maturation } \\
\text { duration } \\
\text { (week) }\end{array}$ & Protein content $\left(\mu \mathrm{g} \mathrm{mg}^{-1}\right.$ f.m.) \\
\hline SEs - TD1 & $\begin{array}{c}5 \\
6 \\
7 \\
8 \\
8 \text { green }\end{array}$ & $\begin{aligned} 74,93 & \pm 7^{\mathrm{b}} \\
96,42 & \pm 9,5^{\mathrm{c}} \\
120,87 & \pm 12,2^{\mathrm{de}} \\
120,38 & \pm 6,8^{\mathrm{de}} \\
50,44 & \pm 6^{\mathrm{a}}\end{aligned}$ \\
\hline SEs - TD15 & $\begin{array}{l}5 \\
6 \\
7 \\
8\end{array}$ & $\begin{array}{ll}105,84 & \pm 9,3^{\mathrm{cd}} \\
108,58 & \pm 11^{\mathrm{cd}} \\
150,71 & \pm 12,4^{\mathrm{f}} \\
130,52 & \pm 4,5^{\mathrm{e}}\end{array}$ \\
\hline ZEs & & $295,25 \pm 31,3^{g}$ \\
\hline megagametophytes & & $551,46 \pm 23,4^{\mathrm{h}}$ \\
\hline
\end{tabular}

Values are means of five repetitions \pm standard error. Significant differences $(p<0.05)$ in a multiple comparison of means are indicated by different letters. 
Version définitive du manuscrit publié dans / Final version of the manuscript published in : Plant Cell, Tissue and Organ Culture, 2018, 132(1) 137-155 http://dx.doi.org/10.1007/s11240-017-1318-0

1115 Table 5 Identification of storage proteins from cotyledonary somatic embryos (SEs) matured for 7 weeks (embryogenic line TD1), zygotic embryos (ZEs) and megagametophyte (mega) from mature dry seed (same full-sib family as SEs) of Douglas-fir. The excised band number refers to the band label indicated in Fig. 8.

\begin{tabular}{|c|c|c|c|c|c|c|c|}
\hline $\begin{array}{c}\text { Band } \\
\mathrm{n}^{\circ}\end{array}$ & Tissue & Accession & Protein assignment & Score & $\%$ covi $^{a}$ & \# pep. ${ }^{b}$ & $\begin{array}{c}\mathrm{MW} \\
(\mathrm{kDa})^{\mathrm{c}}\end{array}$ \\
\hline 1 & SEs & PSME_00010512-RA & $\begin{array}{l}\text { PREDICTED: vicilin-like } \\
\text { antimicrobial peptides } 2-2 \text {, partial }\end{array}$ & 409,2 & 52,61 & 30 & 51,66 \\
\hline 1 & ZEs & PSME_00010512-RA & $\begin{array}{l}\text { PREDICTED: vicilin-like } \\
\text { antimicrobial peptides } 2-2 \text {, partial }\end{array}$ & 622,1 & 58,26 & 34 & 51,66 \\
\hline 1 & mega & PSME_00010516-RA & $\begin{array}{l}\text { PREDICTED: vicilin-like } \\
\text { antimicrobial peptides } 2-2 \text {, partial }\end{array}$ & 1893,8 & 50,22 & 23 & 51,0 \\
\hline 2 & SEs & PSME_00024935-RA & legumin-like storage protein & 31,9 & 31,68 & 8 & 29,63 \\
\hline 2 & SEs & PSME_00010514-RA & $\begin{array}{l}\text { PREDICTED: vicilin-like } \\
\text { antimicrobial peptides } 2-2 \text {, partial }\end{array}$ & 90,2 & 34,72 & 14 & 51,41 \\
\hline 2 & ZEs & PSME_00016325-RA & legumin-like storage protein & 33,1 & 20,07 & 5 & 31,07 \\
\hline 2 & ZEs & PSME_00010514-RA & $\begin{array}{l}\text { PREDICTED: vicilin-like } \\
\text { antimicrobial peptides } 2-2 \text {, partial }\end{array}$ & 98,8 & 38,21 & 15 & 51,41 \\
\hline 2 & mega & PSME_00024935-RA & legumin-like storage protein & 100,0 & 55,73 & 15 & 29,6 \\
\hline 2 & mega & PSME_00026698-RA & $\begin{array}{l}\text { PREDICTED: vicilin-like } \\
\text { antimicrobial peptides } 2-2\end{array}$ & 113,4 & 24,65 & 15 & 57,8 \\
\hline 3 & SEs & PSME_00021143-RA & legumin-like storage protein & 816,1 & 47,21 & 17 & 30,61 \\
\hline 3 & ZEs & PSME_00021143-RA & legumin-like storage protein & 700,3 & 35,69 & 14 & 30,61 \\
\hline 3 & mega & PSME_00025588-RA & legumin-like storage protein & 2014,7 & 58,78 & 20 & 29,6 \\
\hline
\end{tabular}

ao cov.: protein coverage percentage

b\# pep.: number of matching peptides

${ }^{\mathrm{c}}$ Theoretical molecular masses (MW) were taken from the protein used to make the assignment (in Douglas-fir). 


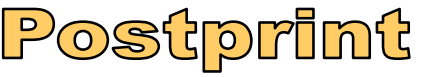

Version définitive du manuscrit publié dans / Final version of the manuscript published in :

Plant Cell, Tissue and Organ Culture, 2018, 132(1) 137-155 http://dx.doi.org/10.1007/s11240-017-1318-0
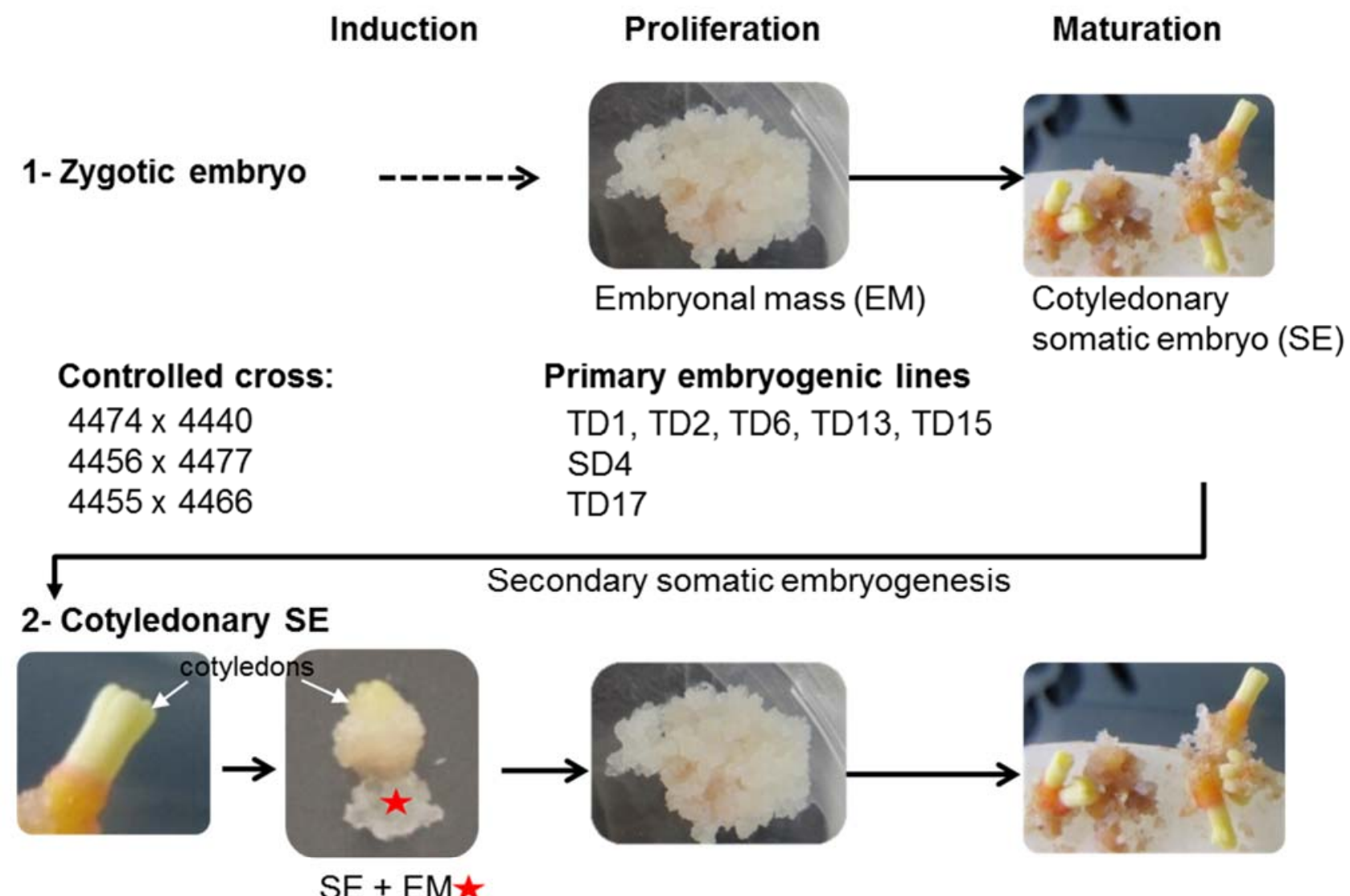

SE from lines:

TD1

TD15

SD4

TD17
Secondary embryogenic lines

TD1-2

TD15-1; TD15-2

SD4-1; SD4-4; SD4-7

TD17-3

Fig.1 


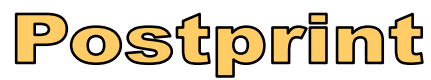

Version définitive du manuscrit publié dans / Final version of the manuscript published in :

Plant Cell, Tissue and Organ Culture, 2018, 132(1) 137-155 http://dx.doi.org/10.1007/s11240-017-1318-0
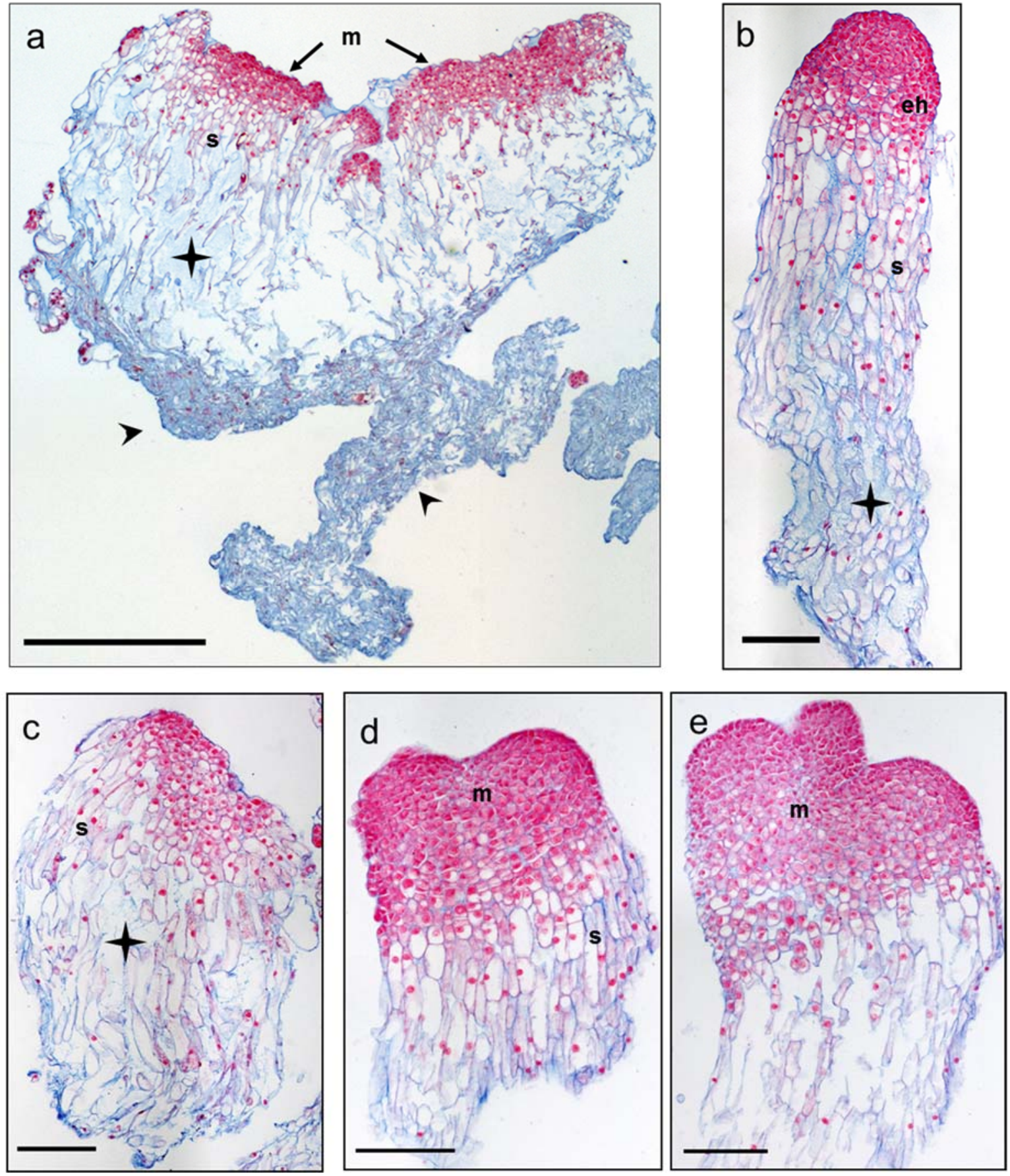

Fig.2 


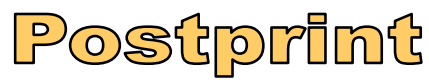

Version définitive du manuscrit publié dans / Final version of the manuscript published in :

Plant Cell, Tissue and Organ Culture, 2018, 132(1) 137-155 http://dx.doi.org/10.1007/s11240-017-1318-0
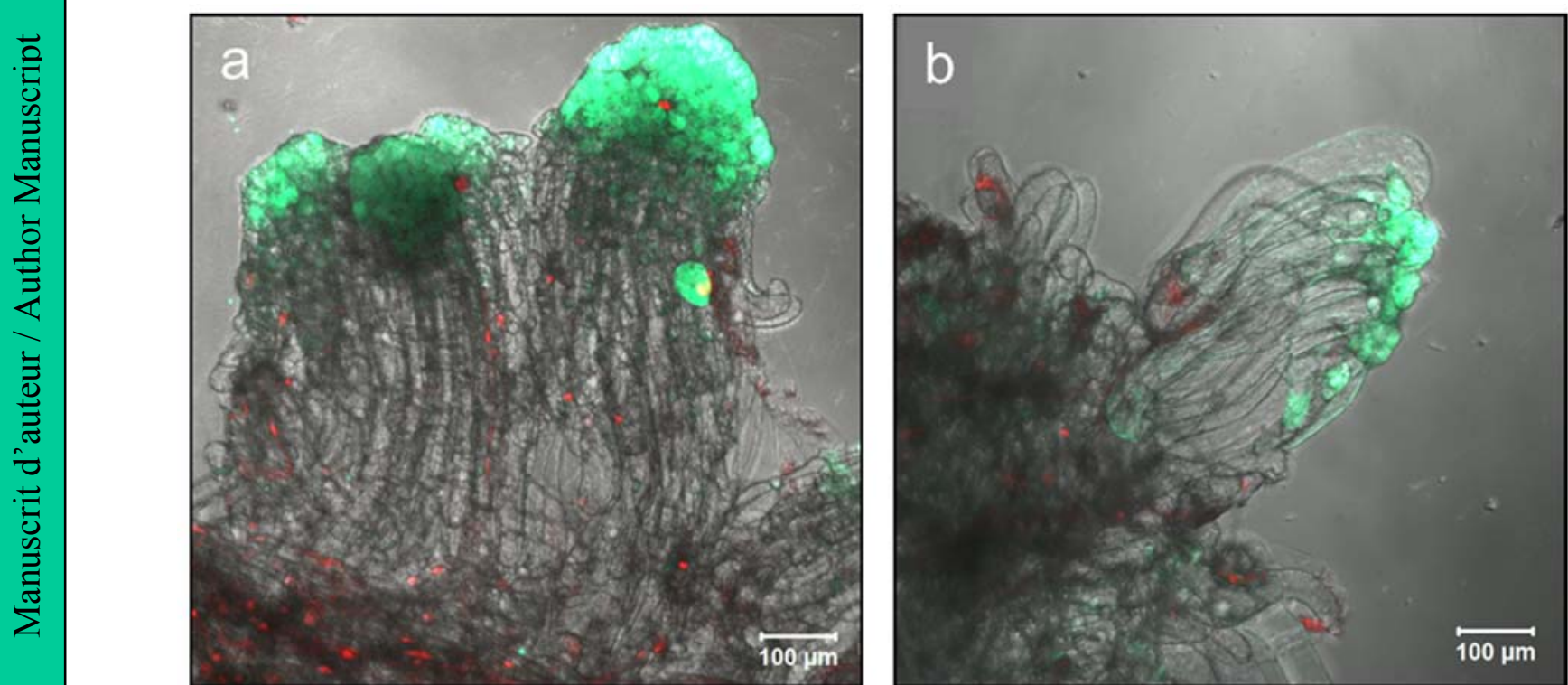

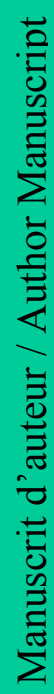
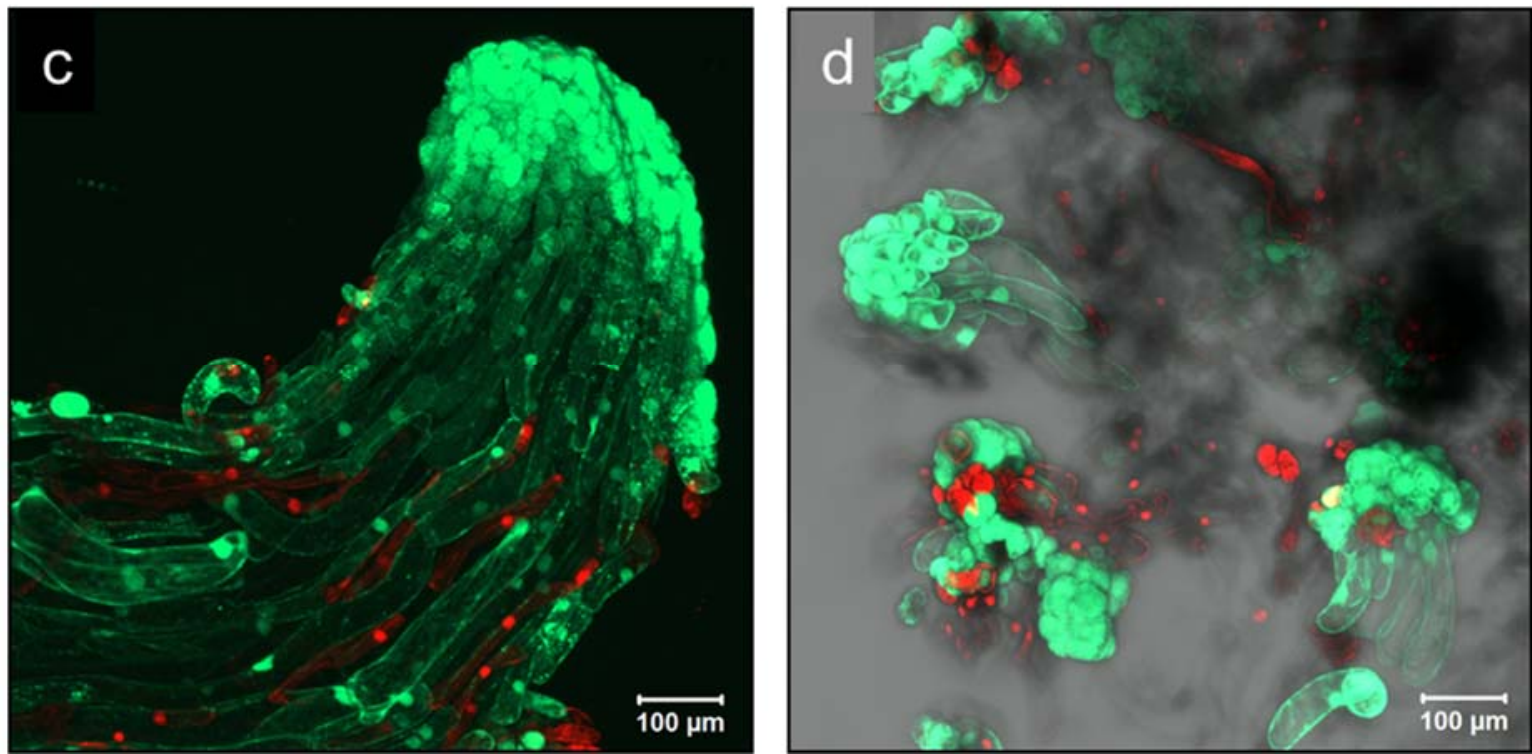

Fig.3

范 
Version définitive du manuscrit publié dans / Final version of the manuscript published in :

Plant Cell, Tissue and Organ Culture, 2018, 132(1) 137-155 http://dx.doi.org/10.1007/s11240-017-1318-0

1142

1143

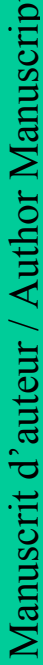

145

1146

1147

는 1148

1149

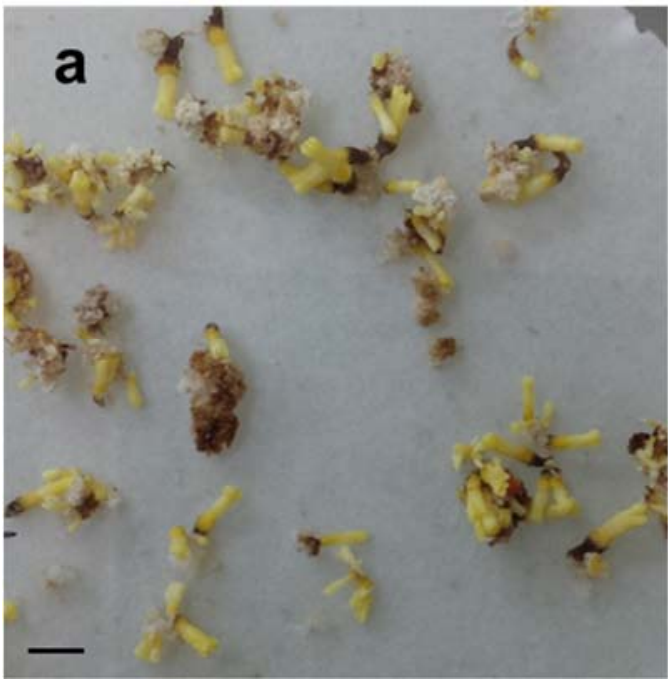

Fig.4

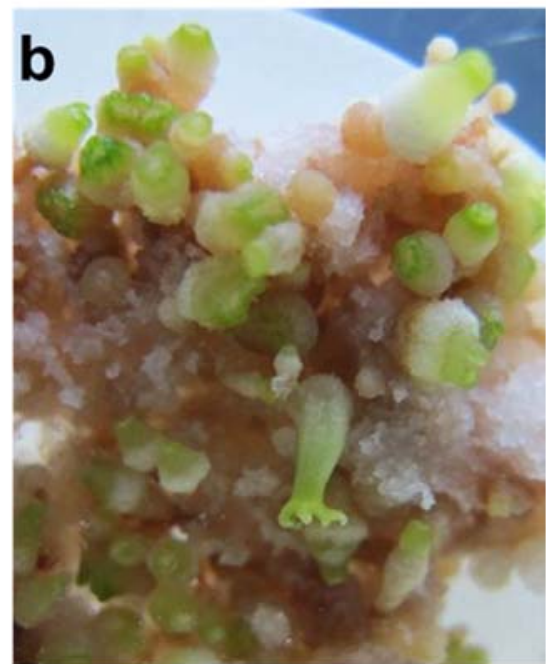


Version définitive du manuscrit publié dans / Final version of the manuscript published in :

Plant Cell, Tissue and Organ Culture, 2018, 132(1) 137-155 http://dx.doi.org/10.1007/s11240-017-1318-0
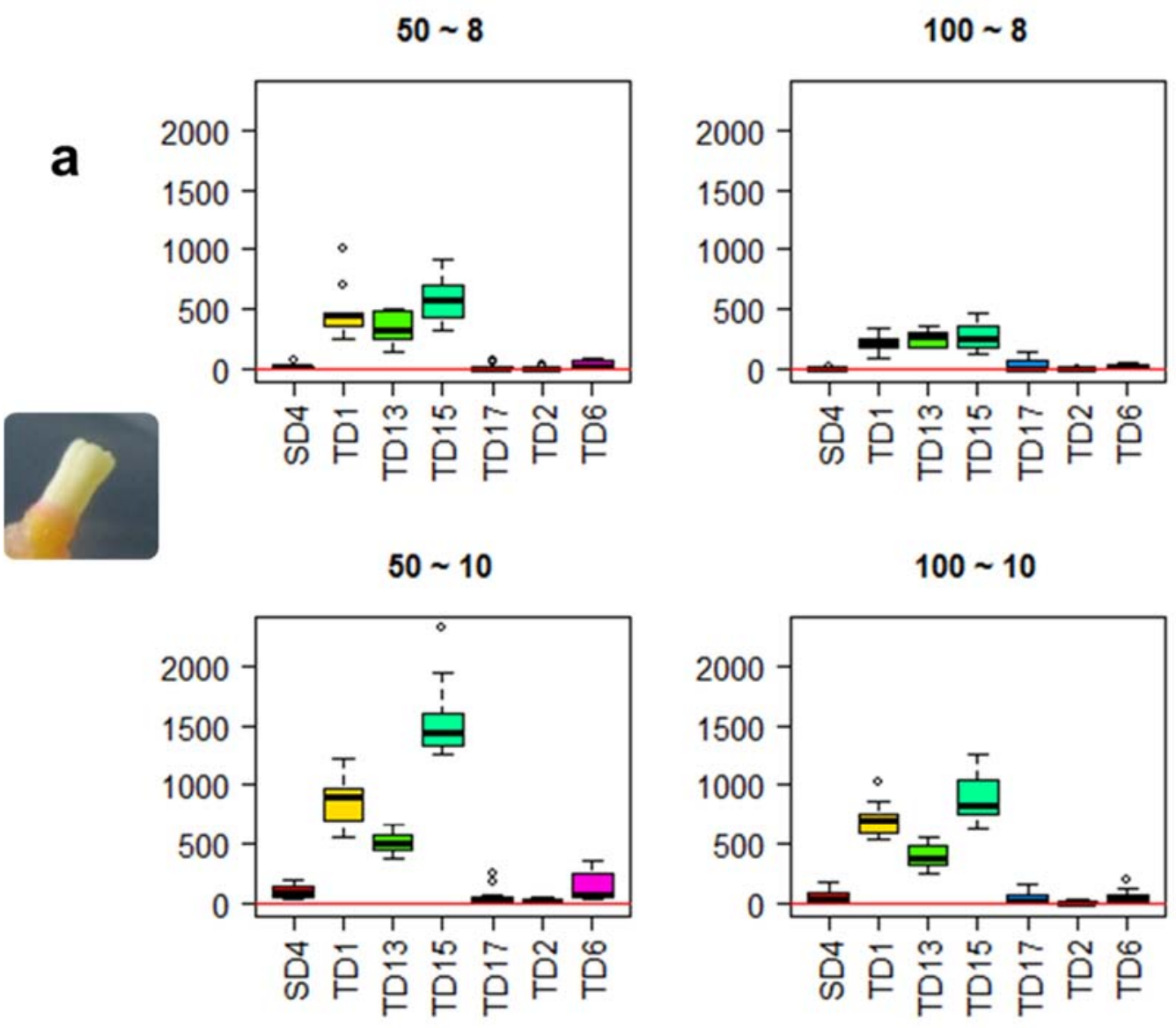

b
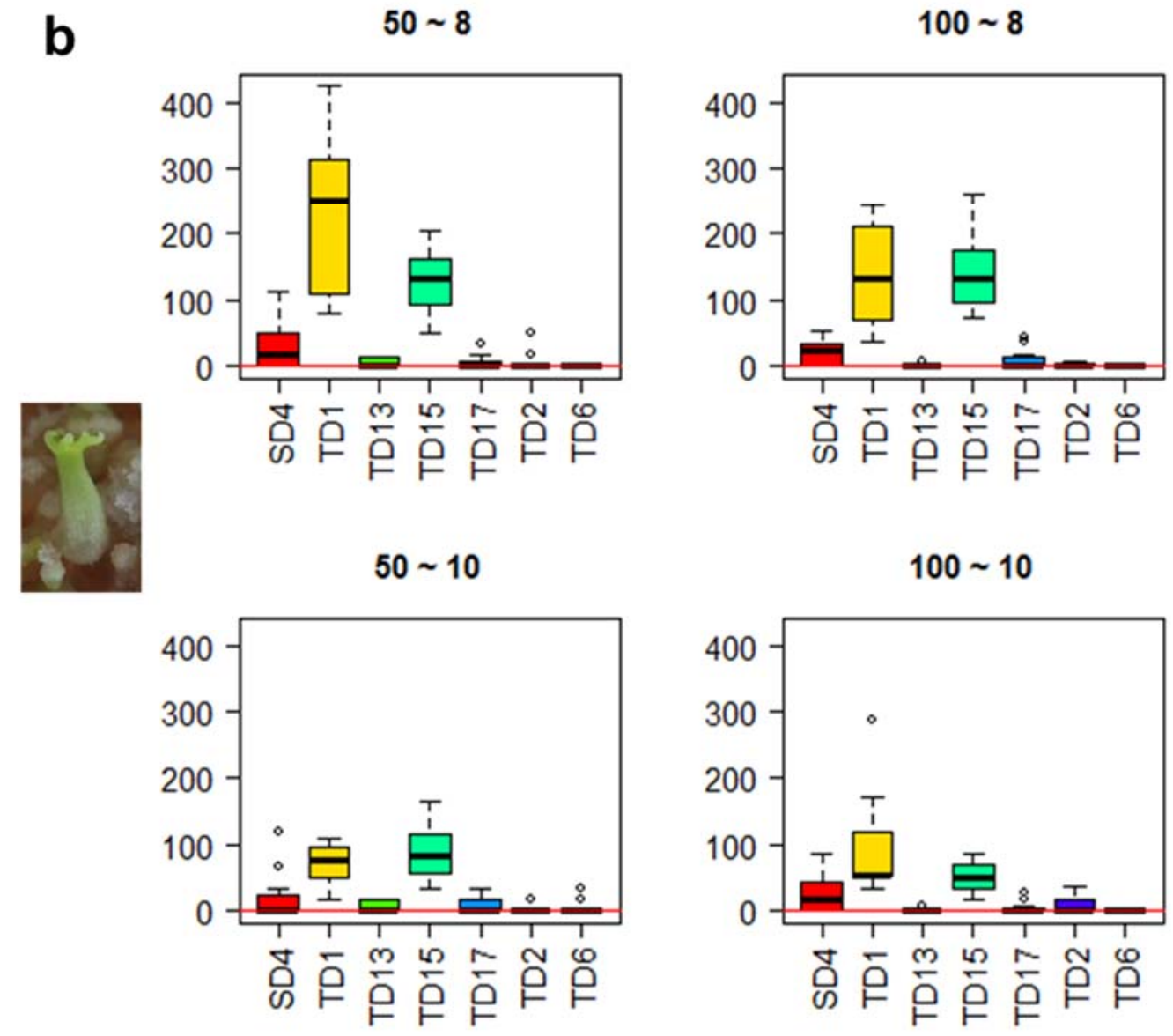

Fig. 5 
Version définitive du manuscrit publié dans / Final version of the manuscript published in :

Plant Cell, Tissue and Organ Culture, 2018, 132(1) 137-155 http://dx.doi.org/10.1007/s11240-017-1318-0

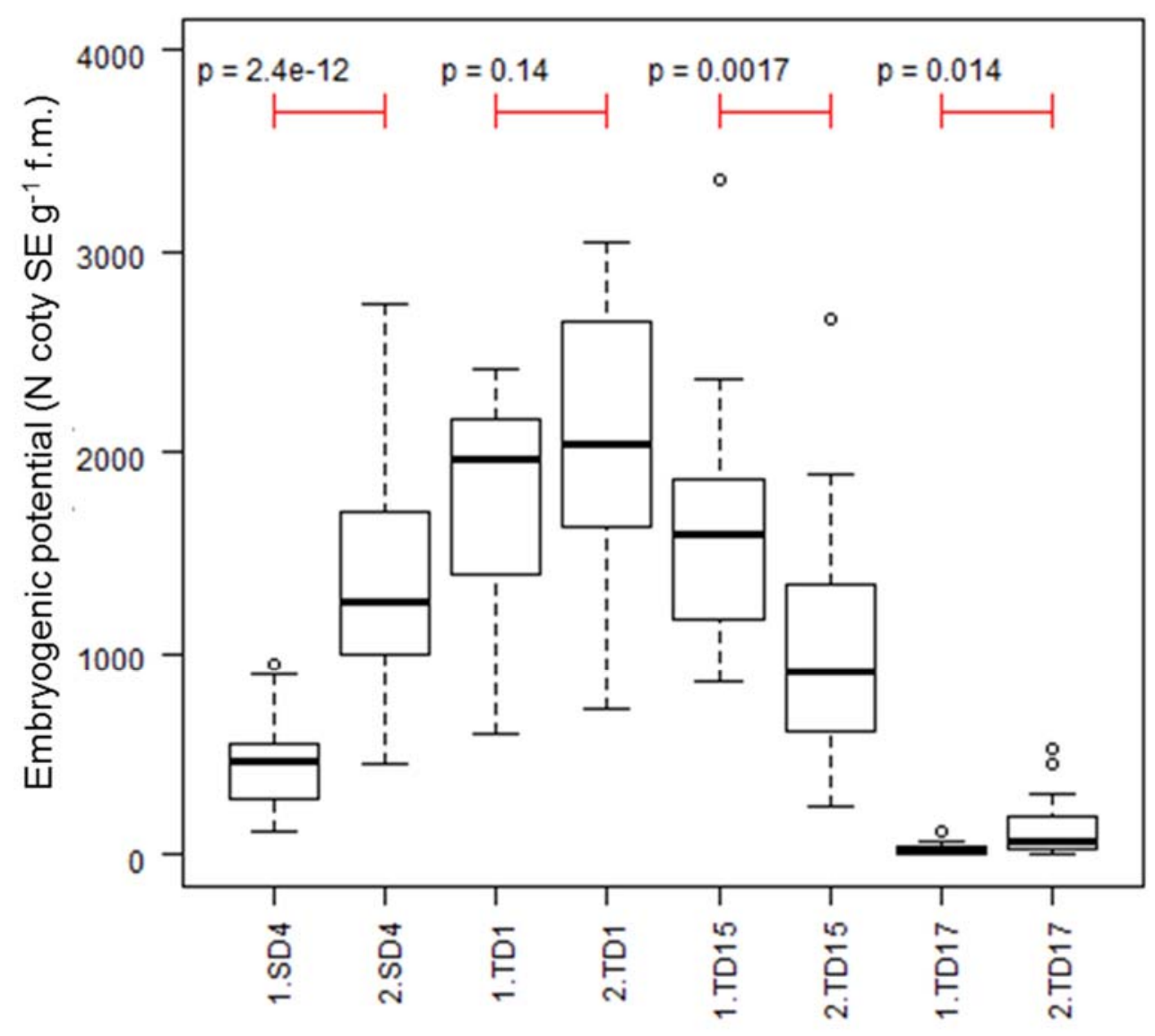

Fig. 6 


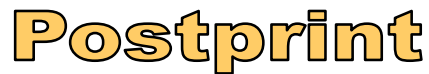

Version définitive du manuscrit publié dans / Final version of the manuscript published in :

Plant Cell, Tissue and Organ Culture, 2018, 132(1) 137-155

http://dx.doi.org/10.1007/s11240-017-1318-0
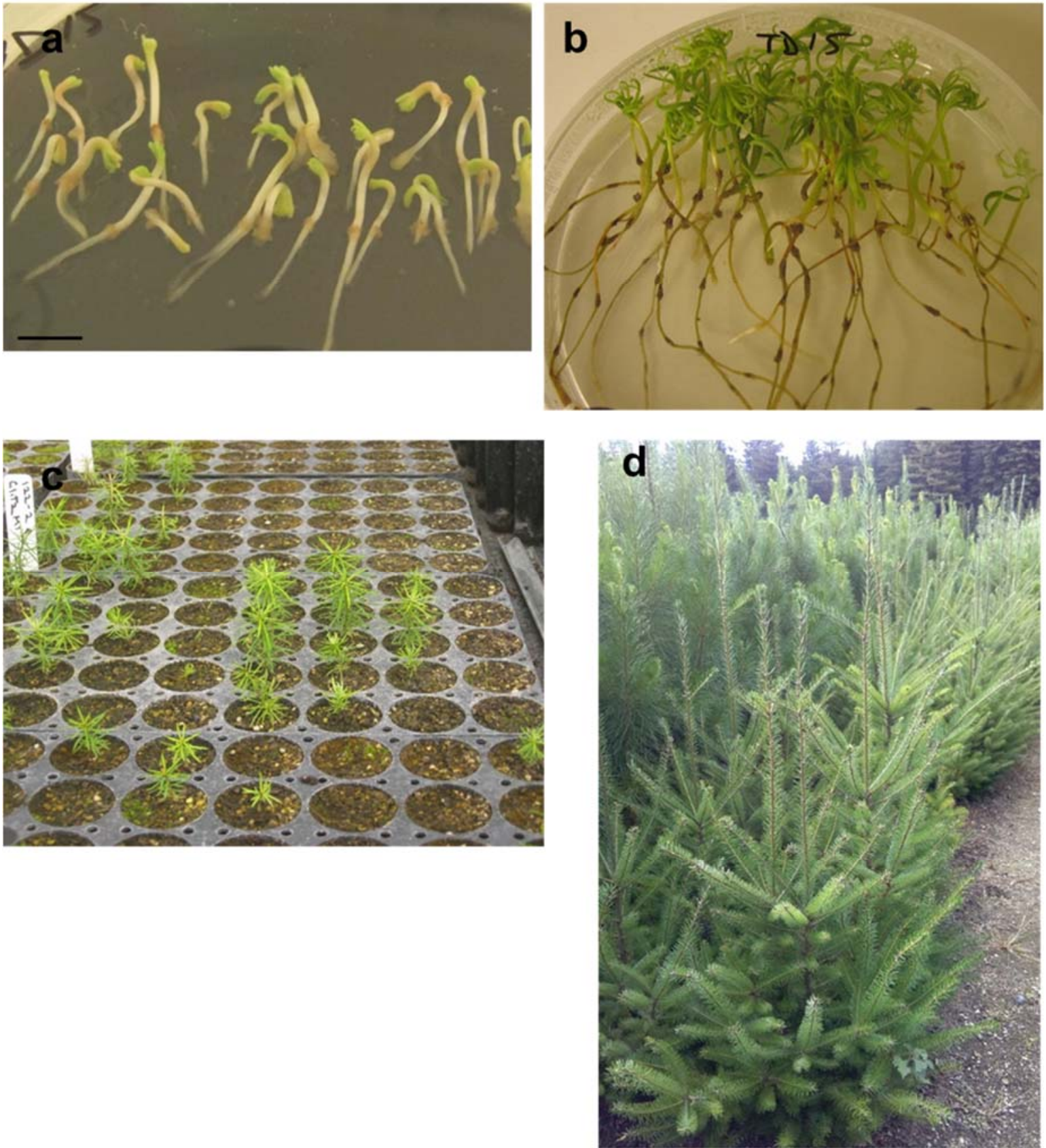

.0.

Fig. 7 
Version définitive du manuscrit publié dans / Final version of the manuscript published in :

Plant Cell, Tissue and Organ Culture, 2018, 132(1) 137-155 http://dx.doi.org/10.1007/s11240-017-1318-0

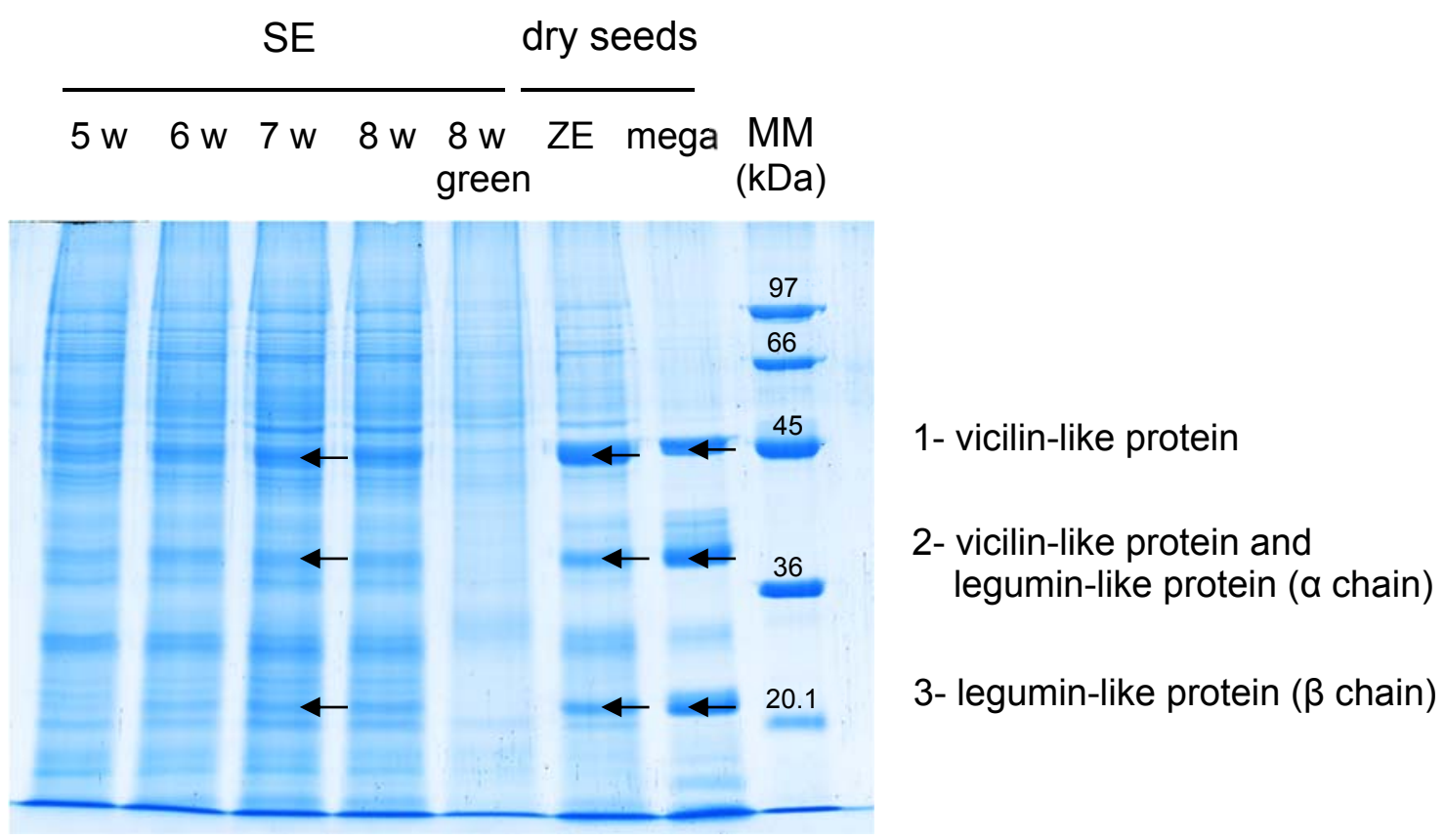

Fig. 8 
Version définitive du manuscrit publié dans / Final version of the manuscript published in :

Plant Cell, Tissue and Organ Culture, 2018, 132(1) 137-155 http://dx.doi.org/10.1007/s11240-017-1318-0

\section{Supporting information}

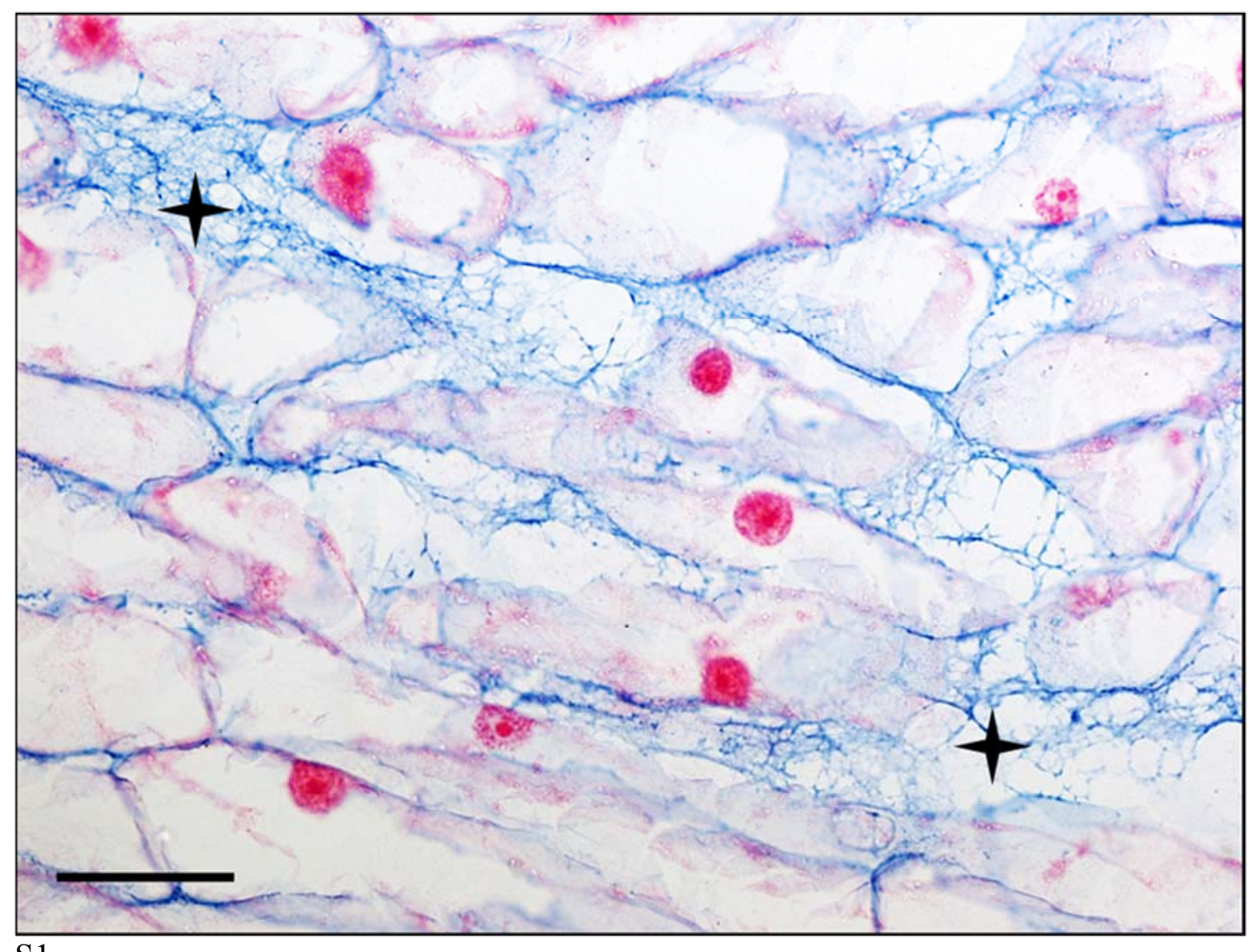




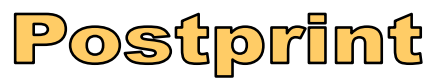

Version définitive du manuscrit publié dans / Final version of the manuscript published in :

Plant Cell, Tissue and Organ Culture, 2018, 132(1) 137-155 http://dx.doi.org/10.1007/s11240-017-1318-0
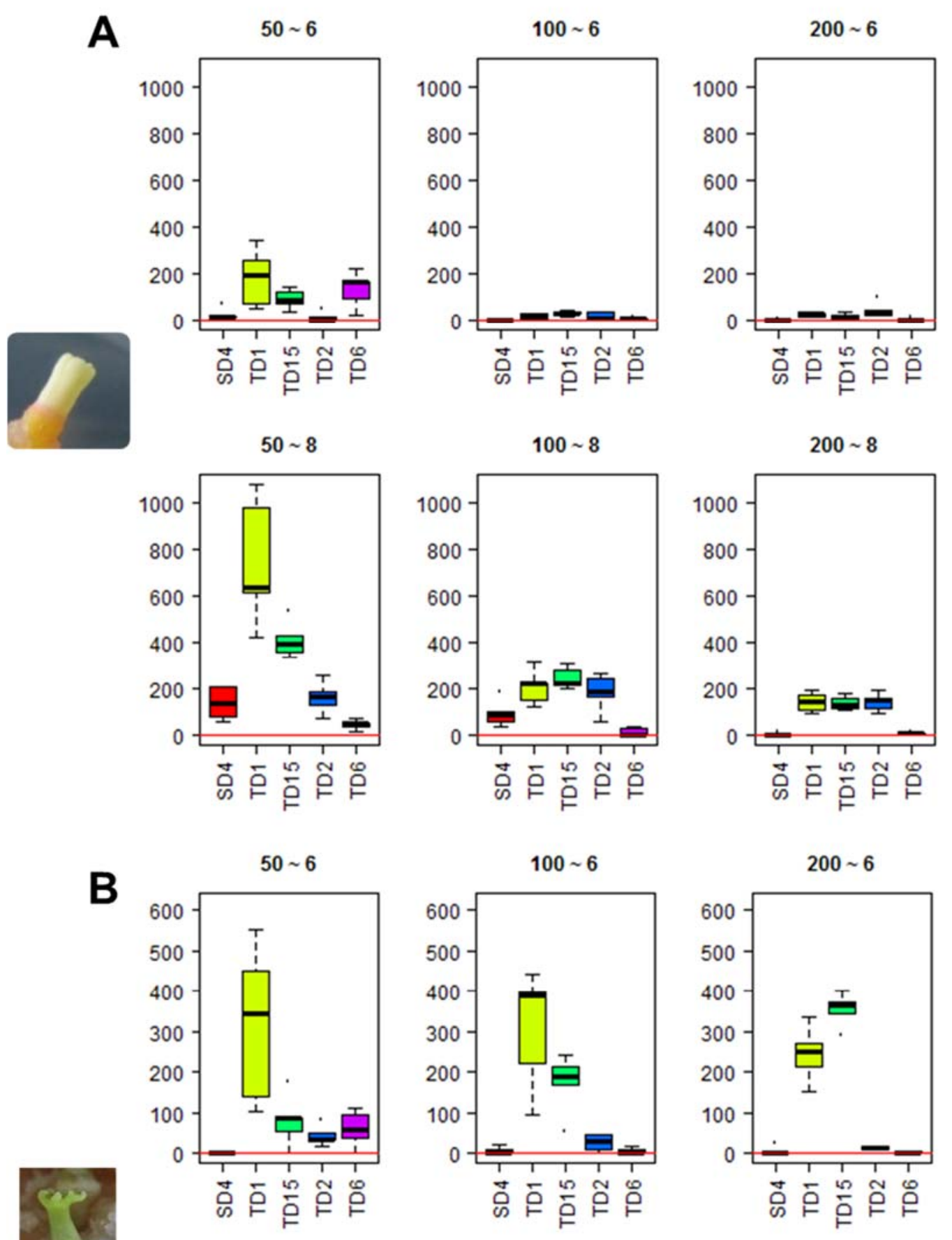

$50 \sim 8$

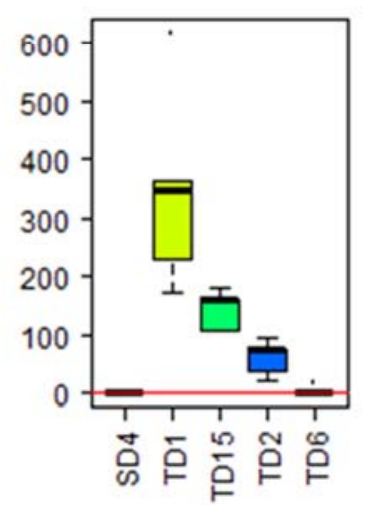

$100 \sim 8$

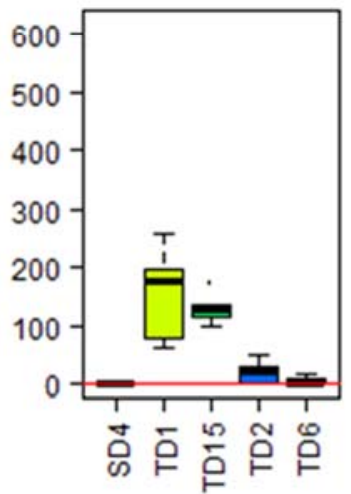

$200 \sim 8$

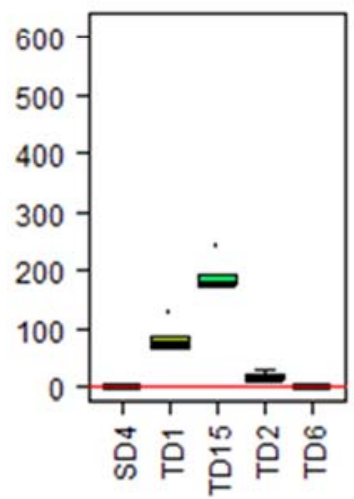

S2 


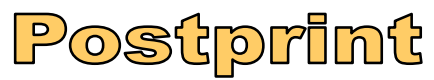

Version définitive du manuscrit publié dans / Final version of the manuscript published in :

Plant Cell, Tissue and Organ Culture, 2018, 132(1) 137-155 http://dx.doi.org/10.1007/s11240-017-1318-0
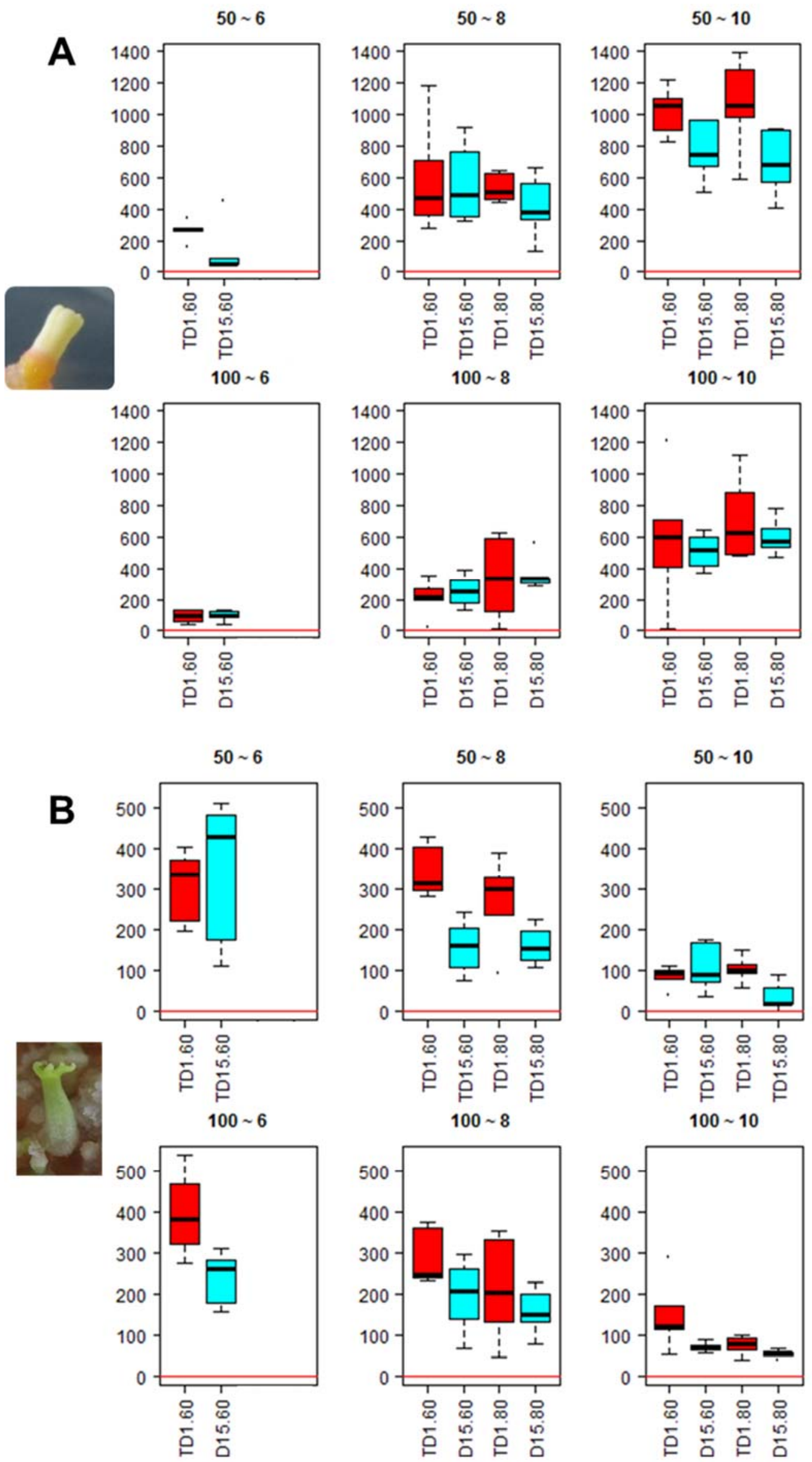
Version définitive du manuscrit publié dans / Final version of the manuscript published in :

Plant Cell, Tissue and Organ Culture, 2018, 132(1) 137-155 http://dx.doi.org/10.1007/s11240-017-1318-0

Supplementary data 4. Germination and plantlet frequencies of cotyledonary somatic embryos (SEs) of Douglas fir according to the presence of activated charcoal (AC) in the germination medium.

\begin{tabular}{|c|c|c|c|c|c|c|}
\hline \multirow[t]{2}{*}{ Genotype } & \multirow{2}{*}{$\begin{array}{c}\mathrm{AC} \\
\left(\mathrm{g} \mathrm{L}^{-1}\right)\end{array}$} & \multirow{2}{*}{$\begin{array}{l}\mathrm{Nb}^{\circ} \text { of SEs } \\
\text { introduced }\end{array}$} & \multicolumn{2}{|c|}{$\mathrm{N}^{\circ}$ SEs germinated } & \multicolumn{2}{|c|}{$\mathrm{N}^{\circ}$ of Plant $*$} \\
\hline & & & Total & $\%$ & Total & $\%$ \\
\hline \multirow[t]{2}{*}{ TD1 } & 0 & 146 & 140 & 96 & 138 & 98 \\
\hline & 10 & 117 & 113 & 96 & 109 & 96 \\
\hline \multirow[t]{2}{*}{ TD2 } & 0 & 56 & 56 & 100 & 52 & 93 \\
\hline & 10 & 73 & 71 & 97 & 37 & 52 \\
\hline \multirow[t]{2}{*}{ TD6 } & 0 & 21 & 20 & 95 & 17 & 85 \\
\hline & 10 & 27 & 25 & 93 & 17 & 68 \\
\hline \multirow[t]{2}{*}{ TD15 } & 0 & 77 & 77 & 100 & 73 & 95 \\
\hline & 10 & 77 & 76 & 99 & 64 & 84 \\
\hline
\end{tabular}

Observed differences between genotypes are not significant for germination rates $\left(\chi^{2}=9.065, p=0.17\right)$ but are significant for conversion rates $(\chi 2=51.044, \mathrm{p}=0.0096)$.

Differences between AC levels are not significant for both germination $(\chi 2=0.525, \mathrm{p}=0.77)$ and conversion rates $(\chi 2=13.73, \mathrm{p}=0.185)$.

* Germination rate was estimated after 4 weeks and conversion rate after 10 weeks on germination medium. SEs were considered germinated as soon as radicle elongation occurred. Germinated SEs were considered to be converted into plantlets as soon as epicotyl development was observed. 